\title{
Pyrenoxy-Based NCN-Pincer Palladium(II) Molecular Tweezers: Synthesis, Properties in Solution and Catalysis
}

\author{
Martijn Q. Slagt, ${ }^{\text {[a] }}$ Johann T. B. H. Jastrzebski, ${ }^{\text {[a] }}$ Robertus J. M. Klein Gebbink, ${ }^{\text {[a] }}$ \\ Hendrik J. van Ramesdonk, ${ }^{[b]}$ Jan W. Verhoeven, ${ }^{[b]}$ Dianne D. Ellis, ${ }^{[c]}$ Anthony L. Spek, ${ }^{[c]}$ and \\ Gerard van Koten*[a]
}

Keywords: Homogeneous catalysis / Palladium / Fluorescence spectroscopy / Ligand design / Pi interactions

\begin{abstract}
A highly flexible molecular tweezer, (aqua)(2,6-bis[(dimethylamino)methyl]-4-\{3-[(1-pyrenyloxy)methyl]-5-(trimethylsilyl)benzyloxy\}phenyl)palladium(II) tetrafluoroborate (1a), constructed from a para-hydroxy-functionalized NCN-pincer palladium(II) complex $\left\{\mathrm{NCN}-\mathrm{OH}=\left[2,6-\left(\mathrm{Me}_{2} \mathrm{NCH}_{2}\right)_{2} \mathrm{C}_{6} \mathrm{H}_{2}-4-\right.\right.$ $\mathrm{OH}]\}$, a pyrenoxy unit and a xylyl spacer, was synthesized. $\mathrm{X}$-ray analysis of the structure of 1-[3-(\{3,5-bis[(dimethylamino)methyl]-4-(trimethylsilyl) phenyloxy\}methyl)-5bromobenzyloxy]pyrene (10), a precursor ligand of $\mathbf{1 a}$, showed a completely flattened conformation in the solid state, imposed by favorable intramolecular $\pi$-stacking interactions. The molecular structure of $\mathbf{1 a}$ in solution proved to be fluxional on the NMR timescale. UV/Vis and (time-resolved) fluorescence spectroscopy revealed that, in spite of the high flexibility, the catalyst and pyrenoxy units are in
\end{abstract}

close proximity because of cation $-\pi$ interactions. This was further supported by conformer searches using molecular mechanics (MM2). The binding affinity of picric acid towards the pyrenoxy moiety was studied by ${ }^{1} \mathrm{H}$ NMR titrations, revealing association constants $K_{\mathrm{a}}$ in the order of $10^{1}$ to $10^{2} \mathrm{M}^{-1}$. Tweezer 1a shows small rate enhancements in aldol condensations of aromatic aldehydes with methyl isocyanoacetate compared to (aqua)(2,6-bis[(dimethylamino)methyl]4 -\{[3-(trimethylsilyl)benzyloxy\}phenyl)palladium(II) tetrafluoroborate (2), which lacks the pyrenoxy unit. The tweezer was immobilized on a G2-carbosilane dendrimer, generating the dendritic (aqua)(G2-carbosilane)palladium complex 1b, showing a decreased catalytic activity compared to 1a. (ㄷ) Wiley-VCH Verlag GmbH \& Co. KGaA, 69451 Weinheim, Germany, 2003)

\section{Introduction}

The use of NCN-pincer complexes $\{\mathrm{NCN}=2,6$-bis[(dimethylamino)methyl]phenyl anion $\}$ as building blocks in the construction of multisite or dendritic catalysts, of supramolecular assemblies and of sensor materials has attracted considerable attention. ${ }^{[1]}$ Synthetic flexibility for the introduction of functional groups, combined with the variety of metallation procedures available, are important issues in their construction. ${ }^{[2]}$ Whereas ligand substitution allows immobilization of transition metal complexes on various support systems, ${ }^{[3]}$ the introduction of functional groups in the vicinity of a metal site can alter its catalytic properties. Both

[a] Debye Institute, Department of Metal-Mediated Synthesis, Utrecht University,

Padualaan 8, $3584 \mathrm{CH}$ Utrecht, The Netherlands

Fax: (internat.) + 31-30/252-3615

E-mail: g.vankoten@chem.uu.nl

[b] Institute of Molecular Chemistry, University of Amsterdam Nieuwe Achtergracht 129, 1018 WS Amsterdam, The Netherlands

[c] Bijvoet Center for Biomolecular Research, Department of Crystal and Structural Chemistry,

Padualaan 8, $3584 \mathrm{CH}$ Utrecht, The Netherlands

Supporting information for this article is available on the WWW under http://www.eurjoc.org or from the author. features are represented in a system published earlier by our group. Catalytic NCN-pincer palladium(II) cationic sites were encapsulated by strategic placement of diphenylsilane moieties and subsequently immobilized on a dendritic backbone. ${ }^{[4]}$ This rather rigid encapsulation of the catalytic site resulted in enhanced reaction rates, but had little influence on the selectivity of the studied aldol reaction catalyzed by the cationic palladium(II) sites. This approach, where functional groups are introduced in the vicinity of the metal site to modify its (catalytic) properties by secondary interactions, has motivated us to construct the new molecular tweezers 1a and $\mathbf{1 b}$ based on a pincer palladium(II) complex and a pyrenoxy moiety, as shown in Scheme 1.

In this paper we report the synthesis of $\mathbf{1 a}, \mathbf{1 b}$ and their relevant variations 2-4 (Scheme 2), according to an approach in which the separately prepared building blocks are assembled on the xylyl spacer group by highly flexible ether linkages. This spacer has an additional reactive site, which allows immobilization on suitable (dendritic) support systems. In 1a, a trimethylsilyl substituent is attached at this anchoring point, serving as a mimic for dimethylsilyl-functionalized carbosilane dendrimers. The dendrimer-immobilized multisite catalyst $\mathbf{1 b}$ contains 36 pyrenoxy-based NCN palladium moieties attached to an inert carbosilane den- 


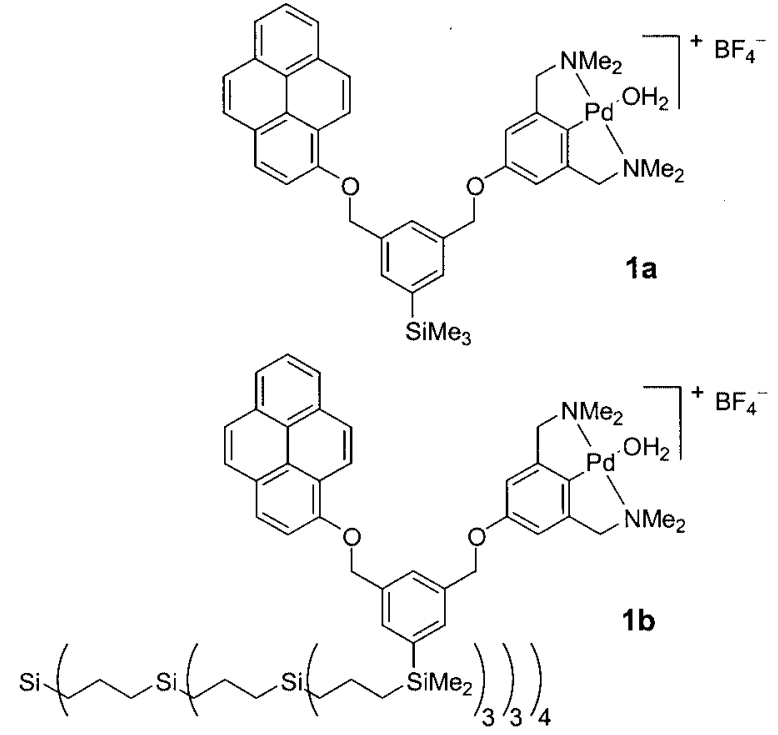

Scheme 1. (Dendritic) NCN palladium(II) complexes $\mathbf{1 a}$ and $\mathbf{1 b}$ functionalized with pyrenoxy units

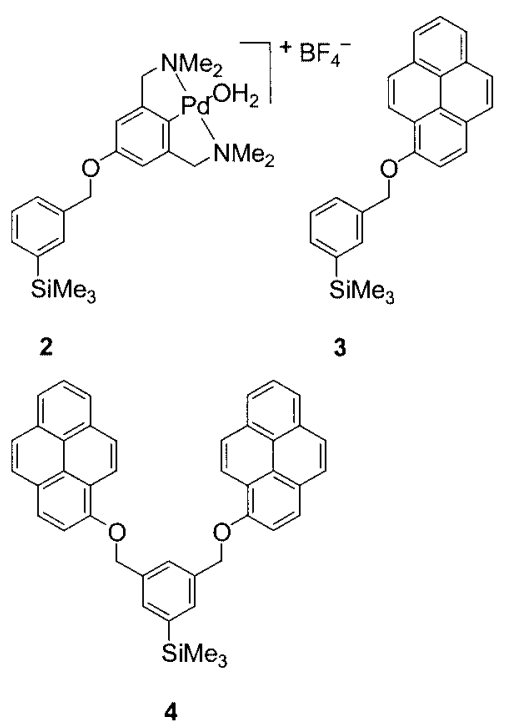

Scheme 2. NCN palladium(II) complex $\mathbf{2}$ and pyrenyl ethers $\mathbf{3}$ and $\mathbf{4}$

drimer. Anchoring these systems to dendrimers allows catalyst recycling by means of nanofiltration techniques. ${ }^{[5]}$ The molecular flexibility of 1a in solution is studied by spectroscopic techniques using the pyrenoxy group as fluorescent probe, and by molecular modeling studies. Furthermore, the influence of the pyrenoxy moiety on the application of 1a as homogeneous catalysts in aldol reactions is described, together with its binding properties to aromatic molecules.

\section{Results}

\section{Synthesis}

Precursor ligand $\mathbf{1 0}$ was synthesized by connecting 1-pyrenol (6) and the NCN-pincer ligand 9 to the linker 3,5bis(bromomethyl)phenyl bromide (5) by ether syntheses

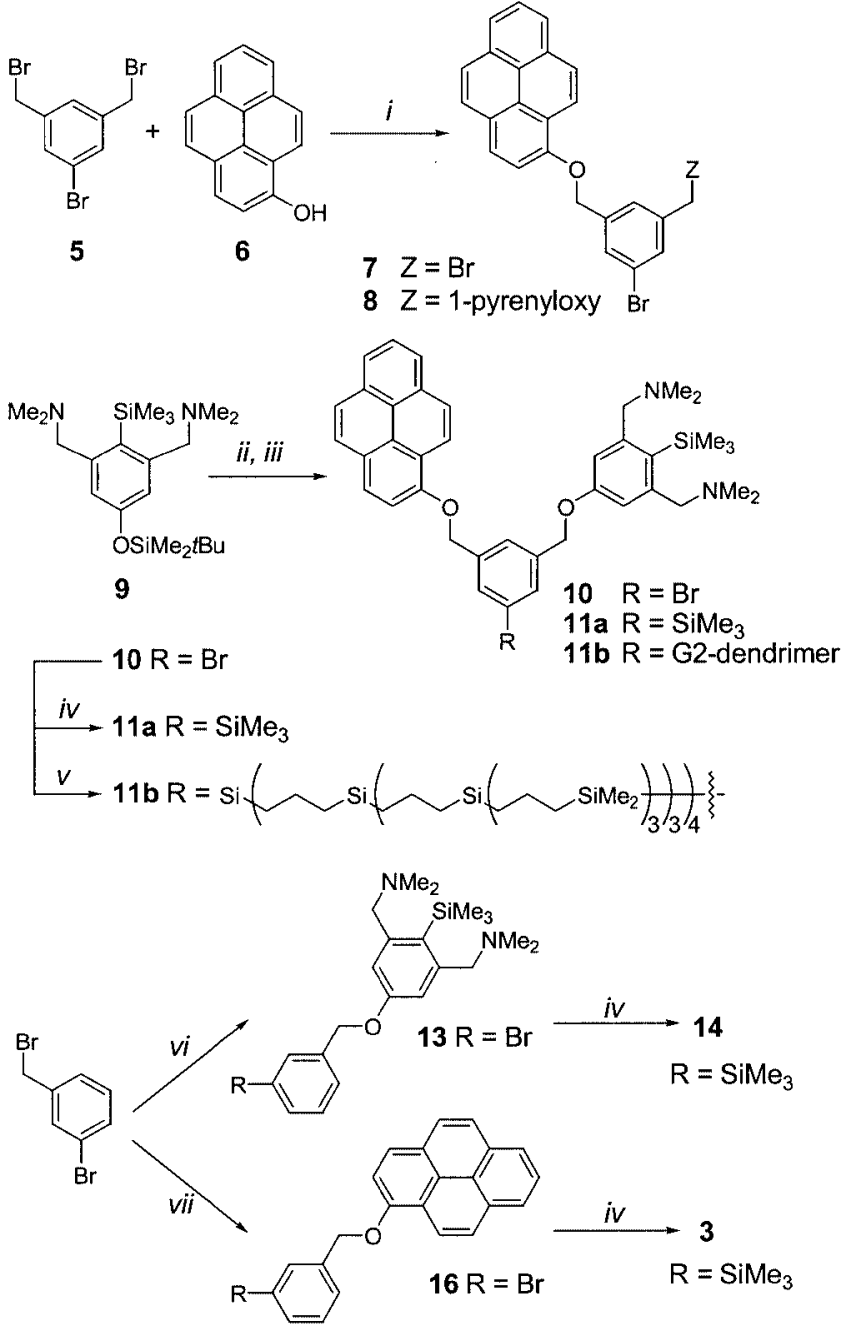

Scheme 3. Synthesis of precursor ligands: i) $\mathrm{K}_{2} \mathrm{CO}_{3}$, 18-crown-6; ii) $\mathrm{Bu}_{4} \mathrm{NF}$; iii) 7, $\mathrm{K}_{2} \mathrm{CO}_{3}$, 18-crown-6; iv) $t \mathrm{BuLi}, \mathrm{Me}_{3} \mathrm{SiCl}$; v) $t \mathrm{BuLi}$, $\mathrm{Si}\left[\left(\mathrm{CH}_{2}\right)_{3} \mathrm{Si}\left\{\left(\mathrm{CH}_{2}\right)_{3} \mathrm{Si}\left[\left(\mathrm{CH}_{2}\right)_{3} \mathrm{SiMe}_{2} \mathrm{Cl}\right]_{3}\right\}_{3}\right]_{4} ;$ vi) $\mathrm{Bu}_{4} \mathrm{NF}, \mathbf{9}, \mathrm{K}_{2} \mathrm{CO}_{3}$, 18-crown-6; vii) $6, \mathrm{~K}_{2} \mathrm{CO}_{3}, 18$-crown-6

(Scheme 3). An excess of tribromide 5 was treated with pyrenoxy unit $\mathbf{6}$ to afford a 1:2:1 mixture of unchanged 5, monofunctionalized 7 and difunctionalized 8 . Selective extraction of $\mathbf{5}$ from the reaction mixture with refluxing pentane afforded a 2:1 mixture of pyrenyl ethers 7 and $\mathbf{8}$. This unresolved mixture was used in the subsequent coupling with 3,5-bis[(dimethylamino)methyl]-4-(trimethylsilyl)phenoxide, which was prepared in situ from 9 by deprotection with tetrabutylammonium fluoride. Purification of the coupling products by careful precipitation of the bis(pyrenyl) ether $\mathbf{8}$ from dichloromethane/pentane afforded pure $\mathbf{1 0}$ in the mother liquor. Precursor ligand $\mathbf{1 0}$ was subsequently attached to either a trimethylsilyl substituent to prepare 11a, or to a G2-carbosilane dendrimer to produce 11b. Reaction of $\mathbf{1 0}$ with $t \mathrm{BuLi}$ followed by treatment with trimethylsilyl chloride or a chlorosilane-functionalized G2-carbosilane dendrimer afforded ligands 11a and 11b, respectively (Scheme 3). Similarly, lithiation of aromatic bromide 8 followed by quenching with $\mathrm{Me}_{3} \mathrm{SiCl}$ afforded bis(pyrenyl) 
ether 4. Ligand 14, the trimethylsilyl precursor of complex $\mathbf{2}$, and pyrenyl ether $\mathbf{3}$ were obtained by similar coupling and lithiation procedures, starting from 3-(bromomethyl)phenyl bromide as anchoring point for either NCN ligand 9 or pyrenoxy unit 6 (Scheme 3 ).

Earlier work by Valk et al. ${ }^{[6]}$ and Steenwinkel et al. ${ }^{[7]}$ had demonstrated that in $\mathrm{R}_{2} \mathrm{NCH}_{2}$-substituted aromatic systems replacement of an ortho-aryl-H by a trimethylsilyl substituent can steer the regioselectivity of an electrophilic palladation reaction. Thus, treatment of $\mathbf{1 1 a}, \mathbf{1 1 b}$ and $\mathbf{1 4}$ with $\mathrm{Pd}(\mathrm{OAc})_{2}$ and subsequent addition of $\mathrm{LiCl}$ led to the selective formation of the corresponding (chloro)palladium(II) complexes 12a, 12b and 15, respectively (Scheme 4). The quantitative metallation of the dendritic polyligand 11b by this mild and selective method is noteworthy. The cationic palladium(II) complexes $\mathbf{1 a}$ and $\mathbf{1 b}$ were prepared from the palladium halide complexes 12a and 12b, respectively. Cationic complex $\mathbf{2}$ was prepared from $\mathbf{1 4}$ in a similar manner. This approach offers the advantage that a wide number of chemical reactions, e.g. lithiation at the linker and subsequent immobilization, can be performed prior to a siteselective metallation step. The (chloro)palladium(II) complexes 12a, 12b and 15, and their corresponding cationic complexes 1a, $\mathbf{1 b}$ and $\mathbf{2}$, can be handled and stored under aerobic and/or moist conditions. However, in concentrated solutions slow decomposition is observed for all complexes, i.e. formation of $\mathrm{Pd}^{0}$. For this reason, the cationic complexes were freshly prepared for use in catalysis.

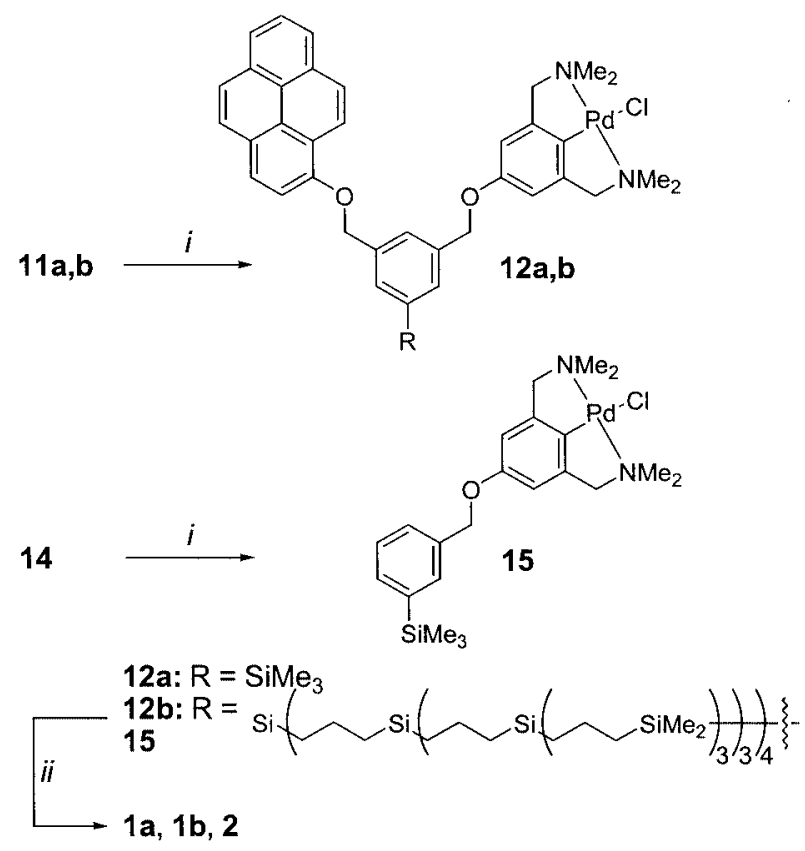

Scheme 4. Synthesis of $\mathbf{1 a}$ and $\mathbf{1 b}$ by site-selective palladation and subsequent halide abstraction: i) $\mathrm{Pd}(\mathrm{OAc})_{2}, \mathrm{LiCl}$; ii) $\mathrm{AgBF}_{4}$

\section{Crystal Structure of $\mathbf{1 0}$}

All attempts to obtain suitable crystals for X-ray analysis of cationic complex 1a or its (chloro)palladium(II) analogue 12a failed. Crystallization of the precursor ligand 10, af-

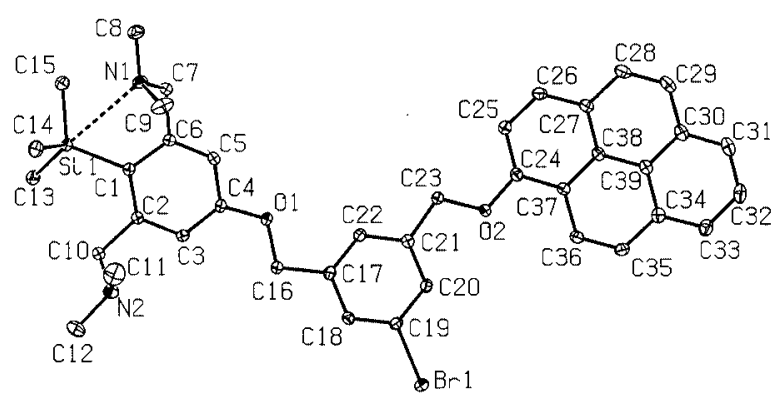

Figure 1. ORTEP representation of $\mathbf{1 0}$ (displacement ellipsoids with $30 \%$ probability); hydrogen atoms are omitted for clarity

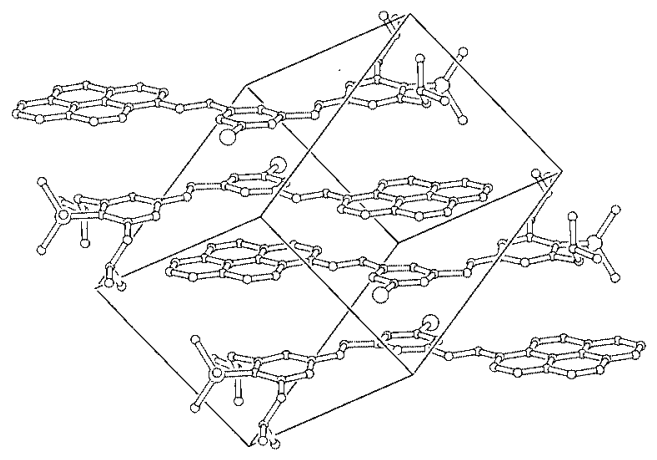

Figure 2. Packing plot of $\mathbf{1 0}$ with unit cell, showing the $\pi$-stacked layered structure

forded suitable crystals for structure determination. The molecular and crystal structure, together with selected bond lengths and angles, are given in Figures 1 and 2, and Table 1.

The structure of $\mathbf{1 0}$ shows both the pincer ligand and the pyrenoxy unit connected to the linker. Interesting aspects of the structure include the silicon center which is $\sigma$-bonded to three methyl groups, to $\mathrm{C}_{i p s o}[\mathrm{C}(1)]$ of the ligand, and in addition has an interaction with one of the ortho- $\mathrm{Me}_{2} \mathrm{NCH}_{2}$ groups. The $\operatorname{Si}(1) \cdots \mathrm{N}(1)$ distance is 3.264(2) $\AA$, which is substantially smaller than the sum of the van der Waals radii of nitrogen and silicon (3.65 $\AA$ ). As a consequence of this hypervalency of silicon, ${ }^{[8]}$ the methyl groups on the silicon atom are distorted from a true tetrahedral geometry, with the $\mathrm{Si}(1)-\mathrm{C}(13)$ bond being significantly longer than the $\mathrm{Si}(1)-\mathrm{C}(14)$ and $\mathrm{Si}(1)-\mathrm{C}(15)$ bonds. Steenwinkel et al. reported an even shorter N $\cdots$. Si contact of $3.040 \AA$ for $\mathrm{Me}_{3} \mathrm{Si}$ substituted NCN-pincer ligands. ${ }^{[7 b]}$

In the crystal lattice, the molecule is completely flattened as a result of crystal packing (Figure 2). The bulky substituents on the ligand, i.e. the $\mathrm{Me}_{3} \mathrm{Si}$ and ortho- $\mathrm{Me}_{2} \mathrm{NCH}_{2}$ substituents, are placed in the crystal lattice in such a way that optimal stacking between the aromatic parts can take place. The requirements for good FFCE (face-to-face, center-toedge) stacking ${ }^{[9]}$ are fulfilled for several intermolecular ring-ring interactions. For example, the interaction between the aromatic ring containing $\mathrm{C}(17)-\mathrm{C}(22)$ and the ring $C(34)-C(39)$ of the neighboring molecule, has the stacking parameters $\alpha=2.9^{\circ}, x=1.8 \AA$ and $z=3.5 \AA$, 
Table 1. Selected bond lengths $[\AA ̊ \cap]$, bond angles $\left[{ }^{\circ}\right]$ and dihedral angles $\left[{ }^{\circ}\right]$ of $\mathbf{1 0}$; the numbering refers to Figure 1

Bond lengths

\begin{tabular}{llll}
\hline $\mathrm{Br}(1)-\mathrm{C}(19)$ & $1.903(2)$ & $\mathrm{O}(1)-\mathrm{C}(16)$ & $1.371(3)$ \\
$\mathrm{N}(1)-\mathrm{C}(7)$ & $1.460(3)$ & $\mathrm{O}(2)-\mathrm{C}(23)$ & $1.419(3)$ \\
$\mathrm{N}(1)-\mathrm{C}(8)$ & $1.463(3)$ & $\mathrm{O}(2)-\mathrm{C}(24)$ & $1.372(3)$ \\
$\mathrm{N}(1)-\mathrm{C}(9)$ & $1.455(3)$ & $\mathrm{Si}(1)-\mathrm{C}(1)$ & $1.909(2)$ \\
$\mathrm{N}(2)-\mathrm{C}(10)$ & $1.467(3)$ & $\mathrm{Si}(1)-\mathrm{C}(13)$ & $1.886(2)$ \\
$\mathrm{N}(2)-\mathrm{C}(11)$ & $1.458(4)$ & $\mathrm{Si}(1)-\mathrm{C}(14)$ & $1.870(3)$ \\
$\mathrm{N}(2)-\mathrm{C}(12)$ & $1.467(4)$ & $\mathrm{Si}(1)-\mathrm{C}(15)$ & $1.879(3)$ \\
$\mathrm{O}(1)-\mathrm{C}(4)$ & $1.371(3)$ & $\mathrm{Si}(1)-\mathrm{N}(1)$ & $3.264(2)$
\end{tabular}

Bond angles

\begin{tabular}{llll}
\hline $\mathrm{C}(4)-\mathrm{O}(1)-\mathrm{C}(16)$ & $117.9(2)$ & $\mathrm{C}(13)-\mathrm{Si}(1)-\mathrm{C}(14)$ & $110.0(1)$ \\
$\mathrm{C}(7)-\mathrm{N}(1)-\mathrm{C}(8)$ & $110.3(2)$ & $\mathrm{C}(13)-\mathrm{Si}(1)-\mathrm{C}(15)$ & $101.1(1)$ \\
$\mathrm{C}(7)-\mathrm{N}(1)-\mathrm{C}(9)$ & $111.5(2)$ & $\mathrm{C}(14)-\mathrm{Si}(1)-\mathrm{C}(1)$ & $112.4(1)$ \\
$\mathrm{C}(8)-\mathrm{N}(1)-\mathrm{C}(9)$ & $109.6(2)$ & $\mathrm{C}(14)-\mathrm{Si}(1)-\mathrm{C}(15)$ & $109.1(1)$ \\
$\mathrm{C}(10)-\mathrm{N}(2)-\mathrm{C}(11)$ & $110.2(2)$ & $\mathrm{C}(15)-\mathrm{Si}(1)-\mathrm{C}(1)$ & $114.9(1)$ \\
$\mathrm{C}(10)-\mathrm{N}(2)-\mathrm{C}(12)$ & $109.1(2)$ & $\mathrm{C}(21)-\mathrm{C}(23)-\mathrm{O}(2)$ & $110.2(2)$ \\
$\mathrm{C}(11)-\mathrm{N}(2)-\mathrm{C}(12)$ & $110.9(2)$ & $\mathrm{O}(23)-\mathrm{O}(2)-\mathrm{C}(24)$ & $117.1(2)$ \\
$\mathrm{C}(13)-\mathrm{Si}(1)-\mathrm{C}(1)$ & $108.7(2)$ & $\mathrm{C}(16)-\mathrm{C}(17)$ & $108.1(2)$
\end{tabular}

Dihedral angles

\begin{tabular}{lrlr}
$\mathrm{C}(3)-\mathrm{C}(2)-\mathrm{C}(10)-\mathrm{N}(2)$ & $46.0(3)$ & $\mathrm{C}(22)-\mathrm{C}(21)-\mathrm{C}(23)-\mathrm{O}(2)$ & $-175.3(2)$ \\
$\mathrm{C}(4)-\mathrm{O}(1)-\mathrm{C}(16)-\mathrm{C}(17)$ & $-173.4(2)$ & $\mathrm{C}(23)-\mathrm{O}(2)-\mathrm{C}(24)-\mathrm{C}(37)$ & $189.1(2)$ \\
$\mathrm{C}(5)-\mathrm{C}(6)-\mathrm{C}(7)-\mathrm{N}(1)$ & $-123.6(2)$ & $\mathrm{C}(24)-\mathrm{O}(2)-\mathrm{C}(23)-\mathrm{C}(21)$ & $179.9(2)$ \\
$\mathrm{C}(16)-\mathrm{O}(1)-\mathrm{C}(4)-\mathrm{C}(5)$ & $171.6(2)$ & $\mathrm{O}(1)-\mathrm{C}(16)-\mathrm{C}(17)-\mathrm{C}(18)$ & $177.0(2)$ \\
\hline
\end{tabular}

which all lie within the boundaries for good FFCE stacking.

\section{UV/Vis, Fluorescence, and ${ }^{\mathbf{1}} \mathrm{H}$ NMR Spectroscopic Studies}

As a result of relatively unhindered rotation around the ether linkages, a wide range of conformations can be adopted by complex 1a in solution. To obtain an indication of the preferred conformation(s) in solution, 1a was subjected to UV/Vis, fluorescence and variable-temperature ${ }^{1} \mathrm{H}$ NMR studies. The highly fluorescent pyrenoxy moiety offers an excellent probe for studying the conformational behavior of this cationic palladium complex. Conformational molecular mechanics studies were performed to obtain more insight.

Variable-temperature ${ }^{1} \mathrm{H}$ NMR studies were performed on a solution of $1 \mathrm{a}$ in $\mathrm{CDCl}_{3}$ between -60 and $+40{ }^{\circ} \mathrm{C}$. At room temperature, the signals corresponding to the benzylic protons of the central linker were broadened. Lowering of the temperature led, apart from broadening of all signals due to an increase in solvent viscosity, to severe broadening of the resonances of these benzylic protons. However, no distinct conformation could be frozen out at $-60{ }^{\circ} \mathrm{C}$. At higher temperatures all signals sharpened, but no other significant changes in the ${ }^{1} \mathrm{H}$ NMR spectrum were observed. The electronic absorption spectrum of cationic palladium(II) complex 1a shows small bathochromic shifts for the longer wavelength bands and significant hypochroism compared to its non-metallated analogue 11a. Besides this, the fluorescence bands of 1a show a bathochromic shift of approximately $5 \mathrm{~nm}$ and a decrease of the relative quantum yield by a factor of $10 .{ }^{[10]}$ Fluorescence-lifetime measurements revealed that the decay curves of 1a and 11a were both due to one-component systems. In dichloromethane, the fluorescence lifetime for $\mathbf{1 a}$ is $1.8 \mathrm{~ns}$ while the lifetime of its non-metallated analogue 11a is 10.6 ns (Figure 3). Immobilization of the system on a G2-carbosilane dendrimer (11b and 1b) almost completely quenched the fluorescence of the pyrenoxy fragment.

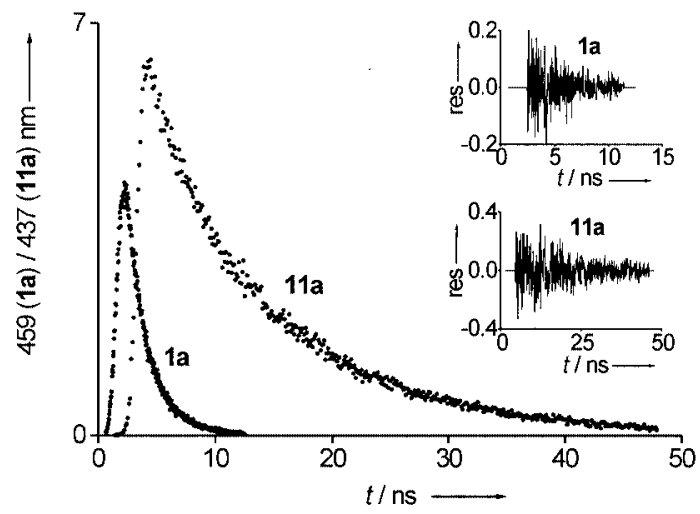

Figure 3. Fluorescence decay curves for $\mathbf{1 a}(\tau=1.8 \mathrm{~ns})$ and 11a $(\tau=10.6 \mathrm{~ns})$

To gain more insight into the flexibility of the 1,3-bis(hydroxymethyl)benzene ethers, bis(pyrenoxy) ether $\mathbf{8}$ was subjected to time-resolved fluorescence spectroscopy. A new emission band $\left(\lambda_{\max }=450 \mathrm{~nm}\right)$ appeared, apart from the 
monomer emission, in the steady-state fluorescence spectrum of $\mathbf{8}$ (Figure 4 , a). This band was attributed to excimer emission, owing to the proximity of two pyrenoxy fragments. The formation of this intramolecular excimer was studied by multiwavelength time-resolved fluorescence spectroscopy using a streak camera in solvents varying in polarity and viscosity.
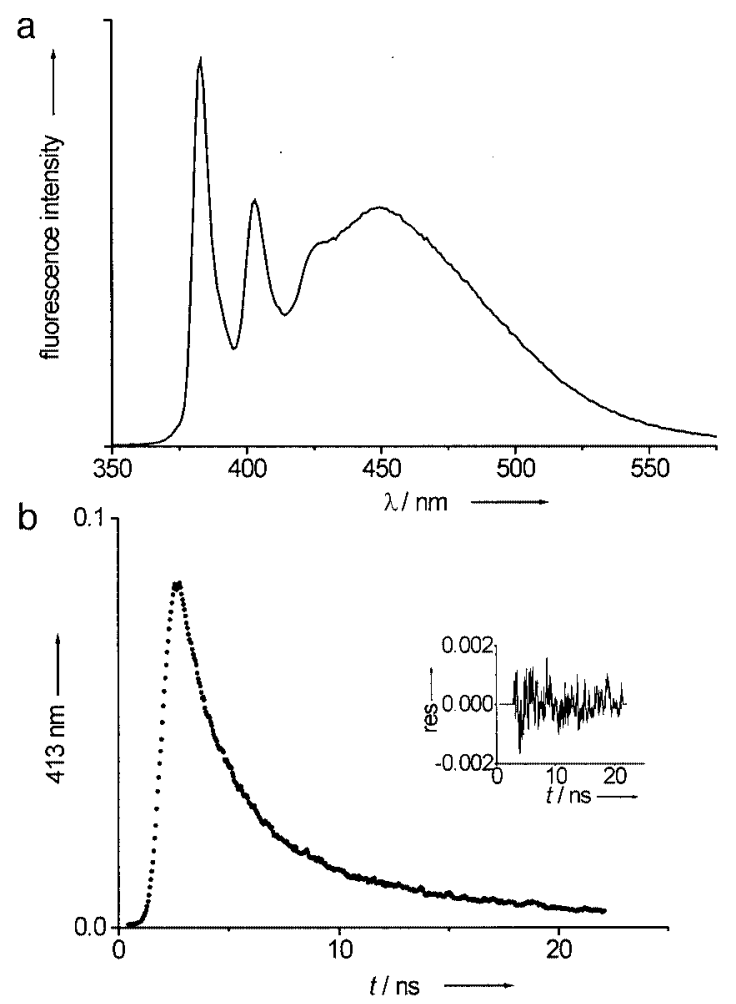

Figure 4. a) Steady-state fluorescence spectrum in hexane and b) fluorescence decay curve of $\mathbf{8}\left(\tau_{1}=10.2 \mathrm{~ns}, \tau_{2}=1.8 \mathrm{~ns}\right)$ in cyclohexane

The fluorescence trace of $\mathbf{8}$ in cyclohexane could be fitted to a biexponential decay with lifetimes of $\tau_{1}=10.2 \mathrm{~ns}$ and $\tau_{2}=1.8 \mathrm{~ns}$ attributed to the local (monomer) and the excimer emission, respectively (Figure $4, \mathrm{~b}$ ). Formation of the excimer from the excited monomer could not be observed, however. In more polar benzonitrile, similar results were obtained ( $\tau_{1}=13.5 \mathrm{~ns}$ and $\tau_{2}=3.8 \mathrm{~ns}$ ), albeit with a lower relative intensity of the excimer band. Since no growth of monomer into excimer fluorescence could be observed, possibly as a result of the speed of excimer formation with respect to detection limits, the solvent was changed to the highly viscous sucrose octaacetate (SOA). Measurements in SOA in the temperature range from 30 to $150{ }^{\circ} \mathrm{C}$ showed a decrease in excimer emission intensity compared to the local fluorescence at higher temperatures. Furthermore, the fine structure in the local fluorescence band was lost. The lifetimes of local and excimer fluorescence were found to be in the same order as in nonviscous solvents $\left(\tau_{1}=20.0 \mathrm{~ns}\right.$ and $\tau_{2}=2.3 \mathrm{~ns}$ at $30^{\circ} \mathrm{C}$ to $\tau_{1}=15.5 \mathrm{~ns}$ and $\tau_{2}=4.8 \mathrm{~ns}$ at $110^{\circ} \mathrm{C}$ ) and as in the previous cases no growth of monomer into excimer fluorescence was observed.

\section{Molecular Mechanics}

The preferred conformations of complex 1a were calculated by conformer searches, allowing stepwise rotation around the six bonds connecting the NCN ligand and the pyrenoxy unit to the linker followed by a molecular mechanics optimization of the structure. All optimized conformers of 1a showed a close proximity $(<5 \AA)$ of the cationic palladium ion and the pyrenoxy unit. In similar conformer searches of 11a, proximity between the NCN ligand $\left(\mathrm{Me}_{3} \mathrm{Si}\right.$ substituent) and the pyrenoxy moiety was not observed as a major conformation. A representation of the structure of the functionalized dendrimer 11b $(26 \mathrm{kD})$ was also calculated by molecular mechanics, showing a densely crowded dendrimer with an average diameter of $5.3 \mathrm{~nm}$.

\section{Binding Studies with Picric Acid}

The binding affinities of 1a, $\mathbf{3}$ and the bis(pyrenyl) ether 4 towards aromatic molecules were studied by ${ }^{1} \mathrm{H}$ NMR titrations with picric acid (2,4,6-trinitrophenol) as guest molecule. Picric acid is known for its ability to form $\pi$ stacking complexes with a wide variety of aromatic molecules. Furthermore, the diagnostic ${ }^{1} \mathrm{H}$ resonances of picric acid are situated in an isolated region of the spectrum. The titration experiments were performed in $\mathrm{CDCl}_{3}$ at constant guest concentrations in the order of $0.5 K_{\mathrm{a}}^{-1}$ to obtain optimal results. ${ }^{[1]}$ In these experiments the upfield shift of the aromatic proton resonance of picric acid was monitored as a function of host/guest ratio. The titration curves were fitted to obtain the association constants and complexationinduced shift values (Table 2). The stoichiometry of the stacking complexes was determined by Job's method of continuous variation for species in rapid exchange. ${ }^{[12]} \mathrm{Job}$ plots of $\Delta \delta \cdot X_{\mathrm{G}}$ versus $X_{\mathrm{G}}\left(\Delta \delta\right.$ : induced shift; $X_{\mathrm{G}}$ : mole fraction of guest) for the supramolecular complexes of picric acid with pyrenoxy-based NCN palladium(II) complex 1a, monopyrenoxy compound $\mathbf{3}$ and bis(pyrenoxy) compound 4 are shown in Figure 5. The maxima in the curves for 1a and 3 are found at $X_{\mathrm{G}}=0.5$ revealing the formation of $1: 1$ complexes. The maximum of the curve in the Job plot of $\mathbf{4}$ is found at $X_{\mathrm{G}}=0.7$ indicating the formation of a 2:1 complex with picric acid.

Table 2. Association constants and complexation induced shift values (CIS) of supramolecular complexes between picric acid and hosts $\mathbf{1 a}, \mathbf{3}$, and $\mathbf{4}$

\begin{tabular}{lll}
\hline & $K_{\mathrm{a}}\left[\mathrm{M}^{-1}\right]^{[\mathrm{a}]}$ & CIS [ppm] \\
\hline $\mathbf{1 a}$ & 94 & -0.67 \\
$\mathbf{3}$ & 44 & -1.08 \\
$\mathbf{4}$ & $81^{[\mathrm{b}]}$ & -0.64 \\
\hline
\end{tabular}

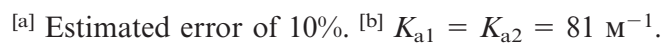

\section{Catalysis - Aldol Condensations}

The cationic NCN palladium(II) complexes $\mathbf{1 a}, \mathbf{1 b}$ and $\mathbf{2}$ can be applied as Lewis acidic catalysts. These types of cationic palladium(II) salts, amongst several other late tran- 


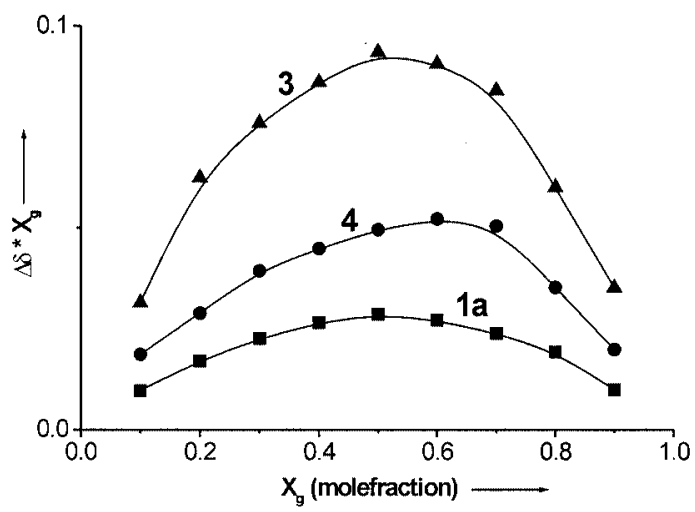

Figure 5. Job plots for complexes between picric acid and pyrenoxy hosts $\mathbf{1 a}, \mathbf{3}$, and $\mathbf{4}$

sition metal salts, have been successfully applied as catalysts in aldol reactions between aldehydes and methyl isocyanoacetate (Scheme 5). ${ }^{[13]}$

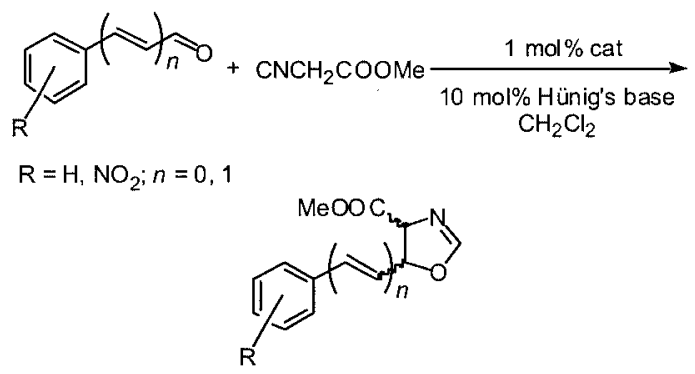

Scheme 5. Aldol condensation of methyl isocyanoacetate with aromatic aldehydes or cinnemaldehydes

Complexes 1a and $\mathbf{2}$ were tested as catalysts in this aldol condensation with several aromatic substrates. All aldol reactions were also performed with a mixture of equimolar amounts of $\mathbf{2}$ and the pyrenyl ether $\mathbf{3}$. Furthermore, multisite catalyst $\mathbf{1 b}$ was applied in the aldol condensation of benzaldehyde to study the effect of immobilization on catalytic performance. The results from the catalytic experiments are collected in Table 3.

\section{Discussion}

The approach in which distinct building blocks are assembled on a multisite linker has been shown to be successful for the synthesis of complex 1a. The strategic positioning of the virtually inert trimethylsilyl substituent on $\mathrm{C}_{i p s o}$ of the NCN-pincer ligand allows regioselective metallation of the ligand at a later stage of the synthesis. Further modifications, such as immobilization on a carbosilane dendrimer (see 1b) appeared to be feasible even after introduction of the ligand, which makes ligand $\mathbf{9}$ a versatile building block for the construction of complex (multimetallic) structures. With this in mind a synthetic route is available which allows the placement of various other functional groups in the vicinity of the cationic NCN-pincer palladium(II) site, apart from the pyrenoxy fluorescent probe in 1a. The third
Table 3. Results from aldol condensations between methyl isocyanoacetate and (nitro-substituted) aldehydes and cinnemaldehydes in dichloromethane in the presence of Hünig's base at ambient temperature

\begin{tabular}{|c|c|c|c|c|c|c|}
\hline \multirow[t]{2}{*}{ Substrate } & \multirow[t]{2}{*}{ Time $[\mathrm{h}]$} & \multicolumn{4}{|c|}{ Conversion $^{[\mathrm{a}]}(\%)$} & \multirow[t]{2}{*}{ cisltrans $^{[\mathrm{b}}$} \\
\hline & & 1a & 2 & $2+3$ & $1 \mathrm{~b}$ & \\
\hline \multirow[t]{2}{*}{$\mathrm{PhCHO}$} & 6 & 48 & 25 & 27 & 11 & 1.82 \\
\hline & 24 & 95 & 91 & 92 & 76 & \\
\hline \multirow[t]{2}{*}{$4-\mathrm{O}_{2} \mathrm{NC}_{6} \mathrm{H}_{4} \mathrm{CHO}$} & 3 & 42 & 41 & 43 & n.d. & 1.98 \\
\hline & 24 & $>99$ & $>99$ & $>99$ & & \\
\hline \multirow[t]{2}{*}{$\mathrm{PhCH}=\mathrm{CHCHO}$} & 5 & 50 & 34 & 30 & n.d. & 1.40 \\
\hline & 24 & $>99$ & 95 & 96 & & \\
\hline \multirow[t]{2}{*}{$2-\mathrm{O}_{2} \mathrm{NC}_{6} \mathrm{H}_{4} \mathrm{CH}=\mathrm{CHCHO}$} & 3 & 49 & 38 & 38 & n.d. & 1.43 \\
\hline & 24 & $>99$ & 97 & 96 & & \\
\hline
\end{tabular}

[a] Determined by ${ }^{1} \mathrm{H}$ NMR spectroscopy. ${ }^{[\mathrm{b}]}$ The cis/trans ratios were identical for catalysts $\mathbf{1 a}, \mathbf{1 b}, \mathbf{2}$, and $\mathbf{2}+\mathbf{3}$; conditions: $1.2 \mathrm{mmol}$ of substrate, $1 \mathrm{~mol} \%$ of catalyst, $10 \mathrm{~mol} \%$ of Hünig's base, $5 \mathrm{~mL}$ of $\mathrm{CH}_{2} \mathrm{Cl}_{2}$, room temperature.

attachment point on the xylyl linker, which in this study has been used for immobilization purposes, can be used for the selective introduction of a third functional moiety on the molecule.

Knowledge of the favored conformations of $\mathbf{1 a}$ in solution is helpful in assessing the influence of the pyrenoxy unit on the catalytic properties of the cationic complex. The polycyclic flat aromatic surface of a pyrenoxy moiety can exhibit interactions with other $\pi$-systems. The $\pi-\pi$ stacking interactions observed in the crystal packing of $\mathbf{1 0}$ are a clear example of this (see Figure 2). This crystal structure also shows that the NCN-pincer moiety itself can be involved in stacking interactions. For the catalysis experiments it is important to know whether the $\pi-\pi$ stacking found in the solid state is also present in dilute solution. In the case of pure 1a, ${ }^{1} \mathrm{H}$ NMR dilution experiments showed no evidence for significant formation or break-up of di- or oligomeric intermolecularly assembled species at the concentrations used in catalysis $\left(10^{-3} \mathrm{M}\right)$. Complexation experiments involving 1a and 3 with picric acid show binding of the aromatic guest molecule to the pyrenoxy moiety by $\pi-\pi$ stacking interactions in a 1:1 ratio, with typical association constants of $10^{1}-10^{2} \mathrm{M}^{-1}$. The bis(pyrenoxy) compound $\mathbf{4}$ can be expected to bind picric acid in two distinct ways. Complexation of one picric acid molecule in a tweezer-type manner, interacting with both pyrenoxy moieties at the same time, results in a 1:1 complex. Alternatively, picric acid molecules can complex to each of the pyrenoxy groups, resulting in the formation of a 2:1 complex. The titration curve and Job plots clearly show that 2:1 complexation occurs, which indicates that there is no significant synergic binding of picric acid by both pyrenoxy units of $\mathbf{4}$.

The flexibility of complex 1a was probed by low-temperature NMR studies, revealing that rotations around the benzyl ether linkages are fast on the NMR timescale, and that preferred conformations could not be frozen out. However, the broadening of these benzylic proton resonances at low temperatures point at hindered rotation. This broadening could result from an attractive interaction between the 
$\mathrm{NCN}$-palladium moiety and the pyrenoxy unit, such as a cation $-\pi$ interaction, bringing the substituents on the xylyl linker into a tweezer-type arrangement. Immobilization of 36 of these units on a G2-carbosilane dendrimer results in a dendrimer with a sterically congested periphery, undoubtedly influencing the flexibility and conformation of the individual units. Interestingly, severe broadening of all proton signals was observed even at room temperature in the polyfunctionalized dendrimers $\mathbf{1 1 b}$ and $\mathbf{1 2 b}$. This can be attributed to the crowded structure of the dendrimer with substituents in various conformations, with ample $\pi-\pi$ stacking interactions. This densely crowded periphery and the formation of various intramolecular (interbranch) $\pi-\pi$ stacking contacts was also observed in molecular-mechanics-optimized structures of $\mathbf{1 1 b}$, and further supported by the quenching of fluorescence in both 11b and $\mathbf{1 2 b}$.

Optical spectroscopic methods offer the possibility of studying the flexibility and conformation of the system on a smaller timescale. Close proximity between the pyrenoxy unit and the cationic palladium(II) site, resulting from cation $-\pi$ interactions, would influence the optical properties of the fluorescent pyrenoxy unit in 1a compared to 11a, which lacks the palladium cation. The $\mathrm{NCN}$-palladium complex and the pyrenoxy moiety are electronically isolated from each other by the linker, hence the influence of the palladium ion on the electronic spectra can only arise from a through-space interaction either inter- or intramolecularly. Since the fluorescence studies were performed at high dilution, we concluded that significant intermolecular interactions were absent. The bathochromic shifts in combination with the observed hypochroism in UV/Vis spectra of 1a compared to 11a imply that the cationic palladium(II) ion is in close proximity to the pyrenoxy site. The presence of this interaction is further supported by fluorescence spectroscopy. The fluorescence decay curves of 1a and 11a differ markedly. Not only is the relative quantum yield decreased by a factor 10 but also its lifetime is significantly reduced. Interactions between the pyrenoxy $\pi$-system and the palladium(II) cation result in (partial) quenching of the pyrenoxy fluorescence. The influence of cation $-\pi$ interactions on the adopted structure of 1a was further supported by molecular mechanics conformation searches. While for 1a all conformations showed a close proximity of the palladium(II) cation and the $\pi$-system, no such preferred conformations were found for the trimethylsilyl analogue 11a. The NCN-palladium(II) complex and the pyrenoxy moiety connected to the xylyl linker thus preferentially adopt a tweezer-type arrangement. The behavior of bis(pyrenoxy) compound $\mathbf{8}$ in time-resolved fluorescence spectroscopy was indicative of a relation between the solvent polarity and the preferential formation of either an "open" or "closed" (tweezer) conformation. While both local (monomer) and excimer bands are observed in the fluorescence spectrum, no interconversion of the excited monomer in the excimer is observed. This behavior can be explained by considering two distinct conformations. First, the pyrenoxy fragments can be in close proximity, resulting in excimer fluorescence upon excitation. Alternatively, when the groups are further apart a rearrangement is necessary to form the excimer after excitation. This rearrangement process is apparently too slow to occur within the lifetime of the monomer fluorescence $(10-20 \mathrm{~ns})$. The relative intensity of the excimer emission compared to the local emission, which decreases with higher solvent polarity, indicates that in less-polar solvents $\mathbf{8}$ does indeed possess a more closed conformation, with the pyrenoxy surfaces close together. The structural relationship between 8 and 1a, i.e. the tweezer-type arrangement of substituents, can allow an extension of these results to the conformation of $\mathbf{1 a}$ in solvents of different polarity.

\section{Catalytic Behavior in Aldol Condensations}

The aldol condensation between methyl isocyanoacetate and aromatic aldehydes or cinnemaldehydes is especially useful for studying the effect of modifications of a Lewis acidic catalyst on its performance. The formation of a mixture of two pairs of diastereoisomers allows monitoring of both the (stereo)selectivity and the activity of the catalyst. These condensations are assumed to occur via coordination of the isocyanoacetate to the metal ion upon replacement of the weakly coordinating water ligand, followed by deprotonation of the coordinated isocyanoacetate to its corresponding enolate. The enolate subsequently reacts with the aldehyde in the rate-determining step to form the product oxazolines as a mixture of the cis and trans isomers. ${ }^{[13 e, 14]}$

Enhancements of up to two times in the initial reaction rates are found for complex 1a compared to complex $\mathbf{2}$. In addition, the presence of pyrenyl ether $\mathbf{3}$ does not affect the reaction rate of the aldol reaction catalyzed by 2 , ruling out any independent effect of the pyrenoxy unit on the catalysis. In the case of 4-nitrobenzaldehyde (Table 3, Entry 2) no influence of the pyrenoxy unit on catalytic performance is observed. The electron-withdrawing nitro substituent activates the aldehyde for nucleophilic attack of the palladiumcoordinated isocyanoacetate enolate. A change in the ratedetermining step resulting from this substrate activation can make the presence or absence of the pyrenoxy unit irrelevant for catalytic performance. The small, but reproducible, rate enhancements observed in the aldol reactions of the other substrates with complex 1a, may be explained by several aspects of this tweezer. First, the cation $-\pi$ interaction activates the catalyst by allowing faster ligand exchange on the metal ion, i.e. exchange of water for methyl isocyanoacetate. Secondly, the presence of the pyrenoxy unit stabilizes one or more of the transition states or intermediates in the catalytic cycle. Stabilization of the protonated ammonium cocatalyst (Hünig's base) by cation $-\pi$ interactions can be envisaged. Thirdly, complexation of the aromatic substrate molecules to the pyrenoxy unit by $\pi-\pi$ stacking interactions would increase their local concentration near the active site. The increased local concentration would facilitate the rate-determining step, resulting in an increased reaction rate. Dendritic multisite complex 1b shows a dramatic fourfold drop in the rate in comparison with complex 1a. This decreased activity can be attributed to the steric crowding, making various catalytic sites inaccessible for substrate molecules. The selectivity, e.g. the cis/ 
trans ratio of the product oxazolines, was found to be independent of the catalyst applied. The pyrenoxy unit does not influence the orientation of the substrate in a (stereo)specific manner towards the coordinated enolate.

\section{Conclusion}

The availability of mild site-selective palladation procedures for NCN-pincer ligands, in combination with their facile para functionalization, allowed us to use them as building block in the construction of organometallic tweezer 1a. The reaction sequence applied in assembling the pyrenoxy, NCN-pincer and xylyl spacer building blocks was flexible enough to allow immobilization of the tweezer on a G2-carbosilane dendrimer, followed by site-selective metallation to produce $\mathbf{1 b}$. The non-immobilized tweezer $\mathbf{1 a}$ is highly flexible and can bind to aromatic substrates (picric acid) by $\pi-\pi$ stacking interactions. It preferentially adopts a tweezer-type conformation in solution as a result of cation $-\pi$ interactions between the palladium(II) ion and the pyrenoxy unit. The abundance of this conformation, compared to a more open one with no interaction between the pyrenoxy and the NCN-palladium unit, appears to be higher in apolar solvents. The minimalistic design approach, with the building blocks simply combined on a flexible linker, leads to observable effects in catalysis. The presence of the pyrenoxy unit in 1a was beneficial for its performance as catalyst in the aldol reaction between methyl isocyanoacetate and aromatic aldehydes. Complex $\mathbf{2}$, which is devoid of a pyrenoxy unit shows lower activities in the aldol condensations, both in the presence and the absence of pyrenyl ether 3. It seems apparent that the close proximity of the pyrenoxy unit and the catalytic palladium(II) site is responsible for the observed rate enhancements.

\section{Experimental Section}

General Remarks: All experiments were conducted under dry nitrogen using standard Schlenk techniques, when using air- and/or water-sensitive reagents. Solvents were dried with appropriate agents and distilled prior to use. The reagent 3,5-bis[(dimethylamino)methyl]phenyl tert-butyldimethylsilyl ether was prepared according to literature procedures. ${ }^{[15]}$ Elemental analyses were performed by $\mathrm{H}$. Kolbe, Mikroanalytisches Laboratorium, Mülheim, Germany. ${ }^{1} \mathrm{H}$ and ${ }^{13} \mathrm{C}$ NMR spectra were recorded at $298 \mathrm{~K}$ with a Varian Inova 300 or Mercury 200 spectrometer. UV/Vis spectra were recorded with a Varian Cary I spectrophotometer.

1-[3-Bromo-5-(bromomethyl)benzyloxylpyrene (7): $\mathrm{K}_{2} \mathrm{CO}_{3} \quad(10 \mathrm{~g}$, $130 \mathrm{mmol})$ was added to a stirred solution of 1-pyrenol (6) $(3.0 \mathrm{~g}$, $14 \mathrm{mmol}), \quad 3,5$-bis(bromomethyl)phenyl bromide (5) (5.30 g, $15 \mathrm{mmol})$ and 18 -crown-6 $(0.3 \mathrm{~g}, 1.3 \mathrm{mmol})$ in THF $(75 \mathrm{~mL})$ and the mixture was stirred at room temperature for $18 \mathrm{~h}$. The volatiles were evaporated in vacuo and the residue was extracted with dichloromethane $(3 \times 50 \mathrm{~mL})$. The combined dichloromethane extracts were concentrated in vacuo, yielding a brownish solid which contained unchanged $\mathbf{5}$, the desired product $\mathbf{7}$ and the disubstituted compound $\mathbf{8}$ in a ratio of approximately 1:2:1. This mixture was extracted with pentane until all unchanged $\mathbf{5}$ was removed (ca. 10 $\times 100 \mathrm{~mL}$ ), yielding $4.23 \mathrm{~g}$ of a $2: 1$ mixture of the mono- and disubstituted products 7 and $\mathbf{8}$ according to ${ }^{1} \mathrm{H}$ NMR integration. This mixture was used in the subsequent step without further purification.

3,5-Bis[(dimethylamino)methyl]-4-(trimethylsilyl)phenyl tert-Butyldimethylsilyl Ether (9): $n \mathrm{BuLi}$ (10.4 mL, $1.6 \mathrm{~m}$ in hexanes, $16.5 \mathrm{mmol}$ ) was added dropwise over a period of $5 \mathrm{~min}$ to a cooled $\left(-78^{\circ} \mathrm{C}\right)$ solution of 3,5-bis[(dimethylamino)methyl]phenyl tert-butyldimethylsilyl ether $(5.16 \mathrm{~g}, 16 \mathrm{mmol})$ in hexane $(20 \mathrm{~mL})$. The reaction mixture was allowed to warm to room temperature and was stirred for an additional $4 \mathrm{~h}$. The reaction mixture was cooled to $0{ }^{\circ} \mathrm{C}$, and a solution of trimethylsilyl trifluoromethylsulfonate $(3.71 \mathrm{~mL}$, $19.2 \mathrm{mmol})$ in THF $(20 \mathrm{~mL})$ was added dropwise over a period of $10 \mathrm{~min}$ and stirring was continued for $1 \mathrm{~h}$ at room temperature. The volatiles were evaporated in vacuo and the residue was subjected to flash chromatography (basic $\mathrm{Al}_{2} \mathrm{O}_{3}, \mathrm{CH}_{2} \mathrm{Cl}_{2}$ ) to afford 9 as a yellow oil. Yield: $5.64 \mathrm{~g}(89 \%) .{ }^{1} \mathrm{H}$ NMR $\left(300 \mathrm{MHz}, \mathrm{C}_{6} \mathrm{D}_{6}, 25^{\circ} \mathrm{C}\right)$ : $\delta=7.14$ (s, $2 \mathrm{H}, \mathrm{ArH}), 3.45\left(\mathrm{~s}, 4 \mathrm{H}, \mathrm{CH}_{2} \mathrm{~N}\right), 2.01$ (s, $\left.12 \mathrm{H}, \mathrm{NMe}_{2}\right)$, 0.99 (s, $9 \mathrm{H}, t \mathrm{BuSi}), 0.46$ (s, $\left.9 \mathrm{H}, \mathrm{SiMe}_{3}\right), 0.18$ (s, $6 \mathrm{H}, \mathrm{SiMe}_{2}$ ) ppm. ${ }^{13} \mathrm{C}$ NMR $\left(75 \mathrm{MHz}, \mathrm{C}_{6} \mathrm{D}_{6}, 25^{\circ} \mathrm{C}\right): \delta=156.4,148.9,130.5,120.7$ (Ar), $65.8\left(\mathrm{CH}_{2} \mathrm{~N}\right), 45.0\left(\mathrm{NMe}_{2}\right), 25.9,-0.4(t \mathrm{BuSi}),-3.6\left(\mathrm{SiMe}_{3}\right)$, -4.2 $\left(\mathrm{SiMe}_{2}\right)$ ppm. $\mathrm{C}_{21} \mathrm{H}_{42} \mathrm{~N}_{2} \mathrm{OSi}_{2}$ (394.7): calcd. C 63.90, H 10.72, N 7.10; found C 63.70, H 10.80, N 6.98.

1-[3-(\{3,5-Bis[(dimethylamino)methyl]-4-(trimethylsilyl)phenyloxy \}methyl)-5-bromobenzyloxylpyrene (10): $\mathrm{NBu}_{4} \mathrm{~F}(6 \mathrm{~mL}, 1 \mathrm{M}$ in THF, $6 \mathrm{mmol})$ was added to a stirred solution of $9(2.22 \mathrm{~g}, 6 \mathrm{mmol})$ in THF $(30 \mathrm{~mL})$. After $30 \mathrm{~min}, \mathrm{~K}_{2} \mathrm{CO}_{3}(5.0 \mathrm{~g}, 30 \mathrm{mmol})$, 18-crown$6(0.15 \mathrm{~g}, 0.6 \mathrm{mmol})$, and the above-mentioned 2:1 mixture of 7 and 8 (4.23 g, contains $5.4 \mathrm{mmol}$ of 7) were added and the reaction mixture was stirred for an additional $18 \mathrm{~h}$. The volatiles were removed in vacuo and subjected to flash chromatography (basic $\mathrm{Al}_{2} \mathrm{O}_{3} ; \mathrm{CH}_{2} \mathrm{Cl}_{2}$ ) resulting in a yellow solid $(5.61 \mathrm{~g})$. The product mixture was redissolved in $\mathrm{CH}_{2} \mathrm{Cl}_{2}$ and careful precipitation of $\mathbf{8}$ with pentane followed by filtration afforded pure $\mathbf{1 0}$ in the mother

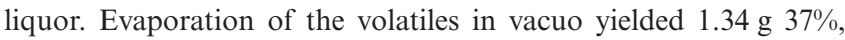
based on 7 of $\mathbf{1 0}$ as a white solid. ${ }^{1} \mathrm{H}$ NMR $\left(300 \mathrm{MHz}, \mathrm{CDCl}_{3}\right.$, $\left.25^{\circ} \mathrm{C}\right): \delta=8.51\left(\mathrm{~d},{ }^{3} J_{\mathrm{H}, \mathrm{H}}=9.2 \mathrm{~Hz}, 1 \mathrm{H}\right.$, pyrenyl), 8.15-7.85 (m, $7 \mathrm{H}$, pyrenyl), 7.69 (s, $1 \mathrm{H}, \mathrm{Ar}), 7.63$ (s, $1 \mathrm{H}, \mathrm{Ar}), 7.58$ (s, $1 \mathrm{H}, \mathrm{Ar}$ ), $7.53\left(\mathrm{~d},{ }^{3} J_{\mathrm{H}, \mathrm{H}}=8.2 \mathrm{~Hz}, 1 \mathrm{H}\right.$, pyrenyl), $7.05(\mathrm{~s}, 2 \mathrm{H}, \mathrm{Ar}), 5.37(\mathrm{~s}, 2$ $\left.\mathrm{H}, \mathrm{CH}_{2} \mathrm{O}\right), 5.09\left(\mathrm{~s}, 2 \mathrm{H}, \mathrm{CH}_{2} \mathrm{O}\right), 3.51\left(\mathrm{~s}, 4 \mathrm{H}, \mathrm{CH}_{2} \mathrm{~N}\right), 2.15(\mathrm{~s}, 12$ $\left.\mathrm{H}, \mathrm{NMe}_{2}\right), 0.37$ (s, $\left.9 \mathrm{H}, \mathrm{SiMe}_{3}\right) \mathrm{ppm} .{ }^{13} \mathrm{C} \mathrm{NMR}\left(75 \mathrm{MHz}, \mathrm{CDCl}_{3}\right.$, $\left.25{ }^{\circ} \mathrm{C}\right): \delta=158.5,151.9,148.3,139.6,139.2,131.4,131.3,129.8$, 129.6, 129.1, 127.0, 126.3, 125.9, 125.5, 125.3, 125.1, 125.0, 124.6, 124.3, 124.2, 124.1, 122.6, 120.9, 120.1, 114.3, 108.9(Ar), 69.2, 68.2

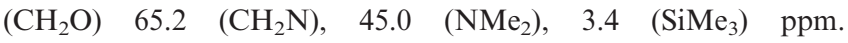
$\mathrm{C}_{39} \mathrm{H}_{43} \mathrm{BrN}_{2} \mathrm{O}_{2} \mathrm{Si}$ (679.8): calcd. C 68.91, H 6.38, N 4.12, Si 4.13; found $\mathrm{C}$ 68.83, $\mathrm{H}$ 6.46, N 3.98, Si 4.23. ES-MS: calculated for $\mathrm{C}_{39} \mathrm{H}_{43} \mathrm{BrN}_{2} \mathrm{O}_{2} \mathrm{Si}\left[\mathrm{M}^{+}+\mathrm{H}\right]$ 679.2; found 680.2.

1-[3-(\{3,5-Bis[(dimethylamino)methyl]-4-(trimethylsilyl)phenyloxy\}methyl)-5-(trimethylsilyl)benzyloxylpyrene (11a): $t \mathrm{BuLi}$ $(1.66 \mathrm{~mL}, 1.5 \mathrm{M}$ in pentane, $2.50 \mathrm{mmol})$ was added dropwise to a precooled $\left(-100{ }^{\circ} \mathrm{C}\right)$ solution of $\mathbf{1 0}(0.84 \mathrm{~g}, 1.25 \mathrm{mmol})$ in THF $(10 \mathrm{~mL})$. The reaction mixture was stirred at $-100{ }^{\circ} \mathrm{C}$ for $1 \mathrm{~h}$ and trimethylsilyl chloride $(0.32 \mathrm{~mL}, 2.55 \mathrm{mmol})$ was added in one portion. The reaction mixture was allowed to warm to room temperature and all volatiles were evaporated in vacuo. After purification by column chromatography (basic $\mathrm{Al}_{2} \mathrm{O}_{3}$; hexane/Et ${ }_{2} \mathrm{O}, 3: 1,3 \%$ TEA) pure 11a was obtained as an off-white solid $(0.81 \mathrm{~g}, 96 \%)$. ${ }^{1} \mathrm{H}$ NMR $\left(300 \mathrm{MHz}, \mathrm{CDCl}_{3}, 25{ }^{\circ} \mathrm{C}\right): \delta=8.53\left(\mathrm{~d},{ }^{3} J_{\mathrm{H}, \mathrm{H}}=9.2 \mathrm{~Hz}\right.$, $1 \mathrm{H}$, pyrenyl), 8.11-8.01 (m, $4 \mathrm{H}$, pyrenyl), 7.96-7.84 (m, $3 \mathrm{H}$, pyrenyl), 7.70 (s, 1 H, Ar), 7.69 (s, $1 \mathrm{H}, \mathrm{Ar}), 7.62$ (s, $1 \mathrm{H}, \mathrm{Ar}), 7.56$ $\left(\mathrm{d},{ }^{3} J_{\mathrm{H}, \mathrm{H}}=8.3 \mathrm{~Hz}, 1 \mathrm{H}\right.$, pyrenyl), $7.08(\mathrm{~s}, 2 \mathrm{H}, \mathrm{Ar}), 5.39(\mathrm{~s}, 2 \mathrm{H}$, 
$\mathrm{CH}_{2} \mathrm{O}$ ), $5.14\left(\mathrm{~s}, 2 \mathrm{H}, \mathrm{CH}_{2} \mathrm{O}\right), 3.51\left(\mathrm{~s}, 4 \mathrm{H}, \mathrm{CH}_{2} \mathrm{~N}\right), 2.14(\mathrm{~s}, 12 \mathrm{H}$, $\mathrm{NMe}_{2}$ ), 0.38 (s, $9 \mathrm{H}, \mathrm{SiMe}_{3}$ ), 0.33 (s, $9 \mathrm{H}, \mathrm{SiMe}_{3}$ ) ppm. ${ }^{13} \mathrm{C} \mathrm{NMR}$ $\left(75 \mathrm{MHz}, \mathrm{CDCl}_{3}, 25{ }^{\circ} \mathrm{C}\right): \delta=159.0,152.8,148.4,141.3,136.8$, 136.6, 132.3, 132.0, 131.6, 129.6, 127.4, 127.2, 126.4, 126.0, 125.8, $125.5,125.4,125.1,124.9,124.3,124.2,121.3,120.6,114.5,109.6$ (Ar), $71.0\left(\mathrm{CH}_{2} \mathrm{O}\right), 69.6\left(\mathrm{CH}_{2} \mathrm{O}\right), 65.4\left(\mathrm{CH}_{2} \mathrm{~N}\right), 45.1\left(\mathrm{NMe}_{2}\right), 3.4$ $\left(\mathrm{SiMe}_{3}\right),-1.1\left(\mathrm{SiMe}_{3}\right)$ ppm. $\mathrm{C}_{42} \mathrm{H}_{52} \mathrm{~N}_{2} \mathrm{O}_{2} \mathrm{Si}_{2}$ (673.1): calcd. C 74.95, H 7.79, N 4.16, Si 8.35; found C 74.86, H 7.88, N 4.20, Si, 8.26.

G2-Carbosilane Dendrimer Ligand 11b: $t \mathrm{BuLi}(0.57 \mathrm{~mL}, 1.5 \mathrm{M}$ in pentane, $0.85 \mathrm{mmol})$ was added dropwise to a precooled $\left(-100^{\circ} \mathrm{C}\right)$ solution of $10(0.30 \mathrm{~g}, 0.45 \mathrm{mmol})$ in THF $(10 \mathrm{~mL})$. The reaction mixture was stirred at $-100{ }^{\circ} \mathrm{C}$ for $1 \mathrm{~h}$ and a solution of $\mathrm{G} 2-(\mathrm{Si}-$ $\left.\mathrm{Me}_{2} \mathrm{Cl}\right)_{36}(68 \mathrm{mg}, 11.2 \mu \mathrm{mol})$ in THF $(5 \mathrm{~mL})$ was added in one portion. The reaction mixture was allowed to warm to room temperature, a few drops of water were added and all volatiles were evaporated in vacuo. The solid was dissolved in dichloromethane $(20 \mathrm{~mL})$ and washed with water $(2 \times 20 \mathrm{~mL})$. The solution was dried with $\mathrm{MgSO}_{4}$ and purified by dialysis against neat dichloromethane. Dendrimer 11b was obtained as a yellowish solid $(0.30 \mathrm{~g})$ in $96 \%$ yield. ${ }^{1} \mathrm{H}$ NMR (300 MHz, $\mathrm{CDCl}_{3}, 25{ }^{\circ} \mathrm{C}$ ): $\delta=8.50-8.30$ (br., 36 H), 8.20-7.70 (br. m, $216 \mathrm{H}$ ) 7.70-7.20 (br. m, $180 \mathrm{H}$ ), 7.07 (br. s, $72 \mathrm{H}, \mathrm{Ar}$ ), 5.30 (br. s, $72 \mathrm{H}, \mathrm{CH}_{2} \mathrm{O}$ ), 5.10 (br., $72 \mathrm{H}, \mathrm{CH}_{2} \mathrm{O}$ ), 3.49 (br. s, $144 \mathrm{H}, \mathrm{CH}_{2} \mathrm{~N}$ ), 2.11 (s, $432 \mathrm{H}, \mathrm{NMe}_{2}$ ), 1.50-1.20 (br. m, dendrimer), $1.00-0.75$ (br. $\mathrm{m}$, dendrimer) $0.75-0.45$ (br. $\mathrm{m}$, dendrimer) $0.45-0.00$ (br. m, dendrimer) 0.12 (s, $324 \mathrm{H}, \mathrm{SiMe}_{3}$ ) ppm. ${ }^{13} \mathrm{C}$ NMR $\left(75 \mathrm{MHz}, \mathrm{CDCl}_{3}, 25{ }^{\circ} \mathrm{C}\right): \delta=159.4,153.0,148.1,140.8$, $136.9,136.8,132.8,132.3,131.9,130.0,127.8,127.4,126.6,126.3$, 126.0, 125.6, 125.3, 125.1, 124.4, 121.6, 120.7, 114.9, 109.7 (Ar), $71.1\left(\mathrm{CH}_{2} \mathrm{O}\right), 70.9\left(\mathrm{CH}_{2} \mathrm{O}\right), 65.4\left(\mathrm{CH}_{2} \mathrm{~N}\right), 45.2\left(\mathrm{NMe}_{2}\right), 23.5,23.1$, 21.8, 21.5, 20.8, 18.9, 18.3, 17.7, $3.7\left(\mathrm{SiMe}_{3}\right), 1.3,-2.5 \mathrm{ppm}$. $\mathrm{C}_{1632} \mathrm{H}_{2076} \mathrm{~N}_{72} \mathrm{O}_{72} \mathrm{Si}_{89}$ (26354.4): calcd. C 74.38, H 7.94, N 3.83, Si 9.48; found C 74.49, H 8.06, N 3.75, Si 9.39.

(2,6-Bis[(dimethylamino)methyl]-4-\{3-[(1-pyrenyloxy)methyl]-5(trimethylsilyl)benzyloxy\}phenyl)palladium(II) Chloride (12a): $\mathrm{Pd}(\mathrm{OAc})_{2}(52 \mathrm{mg}, 0.23 \mathrm{mmol})$ was added to a suspension of 11a $(0.15 \mathrm{~g}, 0.22 \mathrm{mmol})$ in freshly distilled methanol $(5 \mathrm{~mL})$. The reaction mixture was stirred for $3 \mathrm{~h}$ at room temperature after which an excess of $\mathrm{LiCl}$ (42 mg, $1 \mathrm{mmol}$ ) was added and stirring was continued for $1 \mathrm{~h}$. After evaporation of all volatiles in vacuo, the residue was extracted with $\mathrm{CH}_{2} \mathrm{Cl}_{2}(3 \times 10 \mathrm{~mL})$. The combined $\mathrm{CH}_{2} \mathrm{Cl}_{2}$ extracts were filtered through Celite, and evaporation of the solvent afforded $0.16 \mathrm{~g}(99 \%)$ of pure 12a as an off-white solid. ${ }^{1} \mathrm{H} \mathrm{NMR}\left(300 \mathrm{MHz}, \mathrm{CDCl}_{3}, 25{ }^{\circ} \mathrm{C}\right): \delta=8.51\left(\mathrm{~d},{ }^{3} J_{\mathrm{H}, \mathrm{H}}=9.2 \mathrm{~Hz}\right.$, $1 \mathrm{H}$, pyrenyl), 8.14-8.04 (m, $4 \mathrm{H}$, pyrenyl), 8.00-7.85 (m, $3 \mathrm{H}$, pyrenyl), $7.70(\mathrm{~s}, 1 \mathrm{H}, \mathrm{Ar}), 7.65(\mathrm{~s}, 1 \mathrm{H}, \mathrm{Ar}), 7.63\left(\mathrm{~d},{ }^{3} J_{\mathrm{H}, \mathrm{H}}=\right.$ $8.3 \mathrm{~Hz}, 1 \mathrm{H}$, pyrenyl), 7.56 (s, $1 \mathrm{H}, \mathrm{Ar}), 6.44$ (s, $2 \mathrm{H}, \mathrm{Ar}), 5.41$ (s, $2 \mathrm{H}, \mathrm{CH}_{2} \mathrm{O}$ ), 5.00 (s, $2 \mathrm{H}, \mathrm{CH}_{2} \mathrm{O}$ ), 3.82 (s, $4 \mathrm{H}, \mathrm{CH}_{2} \mathrm{~N}$ ), 2.87 (s, 12 $\left.\mathrm{H}, \mathrm{NMe}_{2}\right), 0.34$ (s, $\left.9 \mathrm{H}, \mathrm{SiMe}_{3}\right)$ ppm. ${ }^{13} \mathrm{C} \mathrm{NMR}\left(75 \mathrm{MHz}, \mathrm{CDCl}_{3}\right.$, $\left.25^{\circ} \mathrm{C}\right): \delta=157.0,152.5,145.2,141.2,138.6,136.6,136.5,132.0$, $131.9,131.5,131.4,127.1,127.0,126.3,126.0,125.6,125.3,125.2$, 124.9, 124.6, 124.2, 124.0, 121.0, 120.3, 113.3, 109.4, 106.9 (Ar), $74.4\left(\mathrm{CH}_{2} \mathrm{~N}\right), 70.7\left(\mathrm{CH}_{2} \mathrm{O}\right), 70.4\left(\mathrm{CH}_{2} \mathrm{O}\right), 52.8\left(\mathrm{NMe}_{2}\right),-1.2$ $\left(\mathrm{SiMe}_{3}\right)$ ppm. $\mathrm{C}_{39} \mathrm{H}_{43} \mathrm{ClN}_{2} \mathrm{O}_{2} \mathrm{PdSi}$ (741.7): calcd. C 63.15, H 4.78, $\mathrm{N}$ 3.78; found $\mathrm{C}$ 62.97, $\mathrm{H}$ 4.90, N 3.72. ES-MS: calculated for $\mathrm{C}_{39} \mathrm{H}_{43} \mathrm{ClN}_{2} \mathrm{O}_{2} \mathrm{PdSi}\left[\mathrm{M}^{+}-\mathrm{Cl}\right]$ 705.2; found 705.3.

G2-Carbosilane Dendrimer Palladium Chloride Complex 12b: A solution of $\mathrm{Pd}(\mathrm{OAc})_{2}(26.4 \mathrm{mg}, 117 \mu \mathrm{mol})$ in methanol $(4 \mathrm{~mL})$ was added to a solution of $\mathbf{1 1 b}(70 \mathrm{mg}, 2.61 \mu \mathrm{mol})$ in dichloromethane $(10 \mathrm{~mL})$. The reaction mixture was stirred for $3 \mathrm{~h}$ at room temperature, an excess of $\mathrm{LiCl}(20 \mathrm{mg}, 0.5 \mathrm{mmol})$ was added and stirring was continued for $1 \mathrm{~h}$. After evaporation of all volatiles in vacuo, the residue was extracted with $\mathrm{CH}_{2} \mathrm{Cl}_{2}(3 \times 10 \mathrm{~mL})$. The combined $\mathrm{CH}_{2} \mathrm{Cl}_{2}$ extracts were filtered through Celite, and evaporation of the solvent afforded $60 \mathrm{mg}(2.09 \mu \mathrm{mol}, 80 \%)$ of $\mathbf{1 2 b}$ as a yellow solid. ${ }^{1} \mathrm{H}$ NMR $\left(300 \mathrm{MHz}, \mathrm{CDCl}_{3}, 25^{\circ} \mathrm{C}\right): \delta=8.37$ (br., $36 \mathrm{H}$ ), 8.20-7.65 (m, $216 \mathrm{H}$, pyrenyl), 7.65-7.20 (m, $180 \mathrm{H}$, pyrenyl), 6.32 (br. s, $72 \mathrm{H}, \mathrm{Ar}$ ), $5.21\left(\mathrm{~s}, 72 \mathrm{H}, \mathrm{CH}_{2} \mathrm{O}\right), 4.83$ (s, $72 \mathrm{H}, \mathrm{CH}_{2} \mathrm{O}$ ), 3.65 (s, $144 \mathrm{H}, \mathrm{CH}_{2} \mathrm{~N}$ ), 2.77 (s, $432 \mathrm{H}, \mathrm{NMe}_{2}$ ), 1.50-1.20 (br. m, dendrimer), $1.00-0.75$ (br. $\mathrm{m}$, dendrimer) $0.75-0.45$ (br. $\mathrm{m}$, dendrimer) $0.45-0.00$ (br. m, dendrimer) 0.08 (s, $324 \mathrm{H}, \mathrm{SiMe}_{3}$ ) ppm. ${ }^{13} \mathrm{C}$ NMR $\left(75 \mathrm{MHz}, \mathrm{CDCl}_{3}, 25{ }^{\circ} \mathrm{C}\right): \delta=157.4,152.8,145.7,140.8$, 137.0, 136.8, 132.4, 132.2, 131.8, 130.6, 127.4, 126.7, 126.5, 126.0, 125.7, 125.4, 125.0, 124.7, 124.5, 121.3, 120.7, 109.7, $107.2(\mathrm{Ar})$, $74.8\left(\mathrm{CH}_{2} \mathrm{~N}\right), 71.1\left(\mathrm{CH}_{2} \mathrm{O}\right), 70.8\left(\mathrm{CH}_{2} \mathrm{O}\right), 53.2\left(\mathrm{NMe}_{2}\right), 23.5,23.1$, $21.8, \quad 21.5, \quad 20.8, \quad 18.9, \quad 18.3, \quad 17.7, \quad 1.3,-2.5 \quad$ ppm. $\mathrm{C}_{1524} \mathrm{H}_{1752} \mathrm{Cl}_{36} \mathrm{~N}_{72} \mathrm{O}_{72} \mathrm{Pd}_{36} \mathrm{Si}_{53}$ (28826.3): calcd. C 63.50, H 6.13, N 3.50; found C 63.10, H 6.34, N 3.38.

(Aqua)(2,6-bis[(dimethylamino)methyl]-4-\{3-[(1-pyrenyloxy)methyl]5-(trimethylsilyl)benzyloxy\}phenyl)palladium(II) Tetrafluoroborate (1a): $\mathrm{AgBF}_{4}(45.4 \mathrm{mg}, 0.23 \mathrm{mmol})$ was added to a solution of 12a $(0.16 \mathrm{~g}, 0.22 \mathrm{mmol})$ in wet acetone, resulting in the immediate formation of a white precipitate. The reaction mixture was stirred at room temperature for $1 \mathrm{~h}$ and filtered through Celite. Evaporation of the acetone in vacuo afforded pure $\mathbf{1 a}$ as an off-white solid $(0.18 \mathrm{~g},>99 \%) .{ }^{1} \mathrm{H} \mathrm{NMR}\left(200 \mathrm{MHz}, \mathrm{CDCl}_{3}, 25^{\circ} \mathrm{C}\right): \delta=8.50(\mathrm{~d}$, ${ }^{3} J_{\mathrm{H}, \mathrm{H}}=9.2 \mathrm{~Hz}, 1 \mathrm{H}$, pyrenyl), 8.16-7.85 (m, $7 \mathrm{H}$, pyrenyl), 7.69 (s, $1 \mathrm{H}, \mathrm{Ar}), 7.64(\mathrm{~s}, 1 \mathrm{H}, \mathrm{Ar}), 7.62\left(\mathrm{~d},{ }^{3} J_{\mathrm{H}, \mathrm{H}}=8.3 \mathrm{~Hz}, 1 \mathrm{H}\right.$, pyrenyl), 7.53 (s, $1 \mathrm{H}, \mathrm{Ar}), 6.46$ (s, $2 \mathrm{H}, \mathrm{Ar}), 5.46$ (s, $\left.2 \mathrm{H}, \mathrm{CH}_{2} \mathrm{O}\right), 5.01$ (s, $2 \mathrm{H}, \mathrm{CH}_{2} \mathrm{O}$ ), 3.87 (s, $\left.4 \mathrm{H}, \mathrm{CH}_{2} \mathrm{~N}\right), 2.85$ (s, $12 \mathrm{H}, \mathrm{NMe}_{2}$ ), 0.31 $\left(\mathrm{s}, 9 \mathrm{H}, \mathrm{SiMe}_{3}\right) \mathrm{ppm} .{ }^{13} \mathrm{C} \mathrm{NMR}\left(50 \mathrm{MHz}, \mathrm{CDCl}_{3}, 25^{\circ} \mathrm{C}\right): \delta=$ 157.6, 152.6, 145.2, 143.6, 141.3, 136.6, 136.5, 132.1, 132.0, 131.6, $131.5,127.2,127.1,126.3,126.0,125.7,125.4,125.3,125.0,124.7$, 124.2, 124.1, 121.2, 120.5, 109.7, $107.5(\mathrm{Ar}), 73.8\left(\mathrm{CH}_{2} \mathrm{~N}\right), 70.9$,

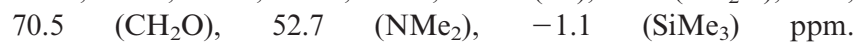
$\mathrm{C}_{39} \mathrm{H}_{45} \mathrm{BF}_{4} \mathrm{~N}_{2} \mathrm{O}_{3} \mathrm{PdSi}$ (811.1): calcd. C 57.75, H 5.59, N 3.45, Si 3.46; found $\mathrm{C} 57.71, \mathrm{H}$ 5.62, N 3.35, Si 3.53. FAB-MS: calculated for $\mathrm{C}_{39} \mathrm{H}_{45} \mathrm{BF}_{4} \mathrm{~N}_{2} \mathrm{O}_{3} \mathrm{PdSi}\left[\mathrm{M}^{+}-\mathrm{BF}_{4}-\mathrm{H}_{2} \mathrm{O}\right]$ 705.2; found 705.1.

G2-Carbosilane Dendrimer (Aqua)palladium Complex 1b: The dendritic (aqua)palladium complex $\mathbf{1 b}$ was prepared in situ for use in the catalytic experiments by treatment of $\mathbf{1 2 b}(6.12 \mathrm{mg}, 0.22 \mu \mathrm{mol})$ with an amount of $\mathrm{AgBF}_{4}(1.56 \mathrm{mg}, 8 \mu \mathrm{mol})$ equimolar with respect to the amount of palladium chloride sites. The complex was not isolated.

5-(3-Bromobenzyloxy)-1,3-bis[(dimethylamino)methyl]-2-(trimethylsilyl)benzene (13): $\mathrm{Bu}_{4} \mathrm{NF}(1 \mathrm{M}$ in THF, $1.6 \mathrm{~mL}, 1.6 \mathrm{mmol}$ ) was added in a single portion to a stirred solution of $9(0.64 \mathrm{~g}, 1.6 \mathrm{mmol})$ in $15 \mathrm{~mL}$ of THF. After $30 \mathrm{~min}, \mathrm{~K}_{2} \mathrm{CO}_{3}(2.0 \mathrm{~g}, 14.5 \mathrm{mmol}), 18-$ crown-6 (50 mg, $0.2 \mathrm{mmol})$ and 3-bromobenzyl bromide $(0.40 \mathrm{~g}$, $1.6 \mathrm{mmol}$ ) were added and the reaction mixture was stirred for an additional $18 \mathrm{~h}$. The volatiles were evaporated in vacuo and the residue was extracted with hexane $(3 \times 20 \mathrm{~mL})$. Purification by chromatography (basic $\mathrm{Al}_{2} \mathrm{O}_{3}$; hexane/Et $2 \mathrm{O}, 3: 1,3 \%$ TEA) afforded 13 as a colorless oil $(0.41 \mathrm{~g}, 60 \%) .{ }^{1} \mathrm{H}$ NMR $\left(200 \mathrm{MHz}, \mathrm{CDCl}_{3}, 25\right.$ $\left.{ }^{\circ} \mathrm{C}\right): \delta=7.63(\mathrm{~s}, 1 \mathrm{H}, \mathrm{Ar}), 7.44\left(\mathrm{~d},{ }^{3} J_{\mathrm{H}, \mathrm{H}}=8.3 \mathrm{~Hz}, 1 \mathrm{H}\right), 7.36(\mathrm{~d}$, $\left.{ }^{3} J_{\mathrm{H}, \mathrm{H}}=7.3 \mathrm{~Hz}, 1 \mathrm{H}\right), 7.23\left(\mathrm{dd},{ }^{3} J_{\mathrm{H}, \mathrm{H}}=8.3,{ }^{3} J_{\mathrm{H}, \mathrm{H}}=7.3 \mathrm{~Hz}, 1 \mathrm{H}\right)$, 7.02 (s, $2 \mathrm{H}, \mathrm{Ar}), 5.05$ (s, $\left.2 \mathrm{H}, \mathrm{CH}_{2} \mathrm{O}\right), 3.50\left(\mathrm{~s}, 4 \mathrm{H}, \mathrm{CH}_{2} \mathrm{~N}\right), 2.14$ (s, $12 \mathrm{H}, \mathrm{NMe}_{2}$ ), 0.37 (s, $9 \mathrm{H}, \mathrm{SiMe}_{3}$ ) ppm. ${ }^{13} \mathrm{C} \mathrm{NMR}(50 \mathrm{MHz}$, $\left.\mathrm{CDCl}_{3}, 25^{\circ} \mathrm{C}\right): \delta=158.6,148.4,139.6,130.8,130.4,130.0,129.9$, $125.9,122.5,114.3(\mathrm{Ar}), 68.6\left(\mathrm{CH}_{2} \mathrm{O}\right), 65.3\left(\mathrm{CH}_{2} \mathrm{~N}\right), 45.1\left(\mathrm{NMe}_{2}\right)$, $3.5\left(\mathrm{SiMe}_{3}\right)$ ppm. $\mathrm{C}_{22} \mathrm{H}_{33} \mathrm{BrN}_{2} \mathrm{OSi}$ (449.5): calcd. C 58.78, H 7.40, N 6.23, Si 6.25; found C 59.02, H 7.34, N 6.21, Si 6.33. 
1,3-Bis[(dimethylamino)methyl]-2-(trimethylsilyl)-5-[3-(trimethylsilyl)benzyloxy]benzene (14): $t \mathrm{BuLi}(1.21 \mathrm{~mL}, 1.5 \mathrm{M}$ in pentane, $1.82 \mathrm{mmol})$ was added dropwise to a precooled $\left(-100^{\circ} \mathrm{C}\right)$ solution of $13(0.41 \mathrm{~g}, 0.91 \mathrm{mmol})$ in diethyl ether $(15 \mathrm{~mL})$, and the reaction mixture was stirred for $1 \mathrm{~h}$ at $-100{ }^{\circ} \mathrm{C}$. Trimethylsilyl chloride $(0.23 \mathrm{~mL}, 1.82 \mathrm{mmol})$ was added dropwise to the yellow solution and the reaction mixture was allowed to warm to room temperature. The volatiles were evaporated in vacuo and the residue was extracted with dichloromethane and filtered through Celite. Purification by chromatography (basic $\mathrm{Al}_{2} \mathrm{O}_{3}$; hexane, 2\% TEA and $\left.\mathrm{Et}_{2} \mathrm{O}, 2 \% \mathrm{TEA}\right)$ afforded $0.22 \mathrm{~g}(55 \%)$ of pure $\mathbf{1 4}$ as a colorless oil. ${ }^{1} \mathrm{H}$ NMR $\left(200 \mathrm{MHz}, \mathrm{CDCl}_{3}, 25{ }^{\circ} \mathrm{C}\right): \delta=7.64(\mathrm{~s}, 1 \mathrm{H}, \mathrm{Ar})$, 7.57-7.37 (m, $3 \mathrm{H}, \mathrm{Ar}), 7.09$ (s, $2 \mathrm{H}, \mathrm{Ar}), 5.13$ (s, $\left.2 \mathrm{H}, \mathrm{CH}_{2} \mathrm{O}\right), 3.55$ (s, $4 \mathrm{H}, \mathrm{CH}_{2} \mathrm{~N}$ ), 2.18 (s, $12 \mathrm{H}, \mathrm{NMe}_{2}$ ), 0.42 (s, $\left.9 \mathrm{H}, \mathrm{SiMe}_{3}\right), 0.33$ (s, $\left.9 \mathrm{H}, \mathrm{SiMe}_{3}\right)$ ppm. ${ }^{13} \mathrm{C} \mathrm{NMR}\left(50 \mathrm{MHz}, \mathrm{CDCl}_{3}, 25^{\circ} \mathrm{C}\right): \delta=$ $159.0,148.3,140.6,136.2,132.8,132.6,129.5,128.2,127.8,114.5$ (Ar), $69.8\left(\mathrm{CH}_{2} \mathrm{O}\right), 65.4\left(\mathrm{CH}_{2} \mathrm{~N}\right), 45.5\left(\mathrm{NMe}_{2}\right), 3.4\left(\mathrm{SiMe}_{3}\right),-1.1$ $\left(\mathrm{SiMe}_{3}\right)$ ppm. $\mathrm{C}_{25} \mathrm{H}_{42} \mathrm{~N}_{2} \mathrm{OSi}_{2}$ (442.8): calcd. C 67.81, H 9.56, N 6.33, Si 12.69; found C 67.75, H 9.49, N 6.28, Si 12.48 .

\{2,6-Bis[(dimethylamino)methyl]-4-[3-(trimethylsilyl)benzyloxy]phenyl palladium(II) Chloride (15): $\mathrm{Pd}(\mathrm{OAc})_{2}(0.12 \mathrm{~g}, 0.52 \mathrm{mmol})$ was added to a suspension of $\mathbf{1 4}(0.22 \mathrm{~g}, 0.5 \mathrm{mmol})$ in freshly distilled methanol. The reaction mixture was stirred for $45 \mathrm{~min}$, during which a yellow precipitate formed. $\mathrm{LiCl}(0.21 \mathrm{~g}, 5.0 \mathrm{mmol})$ was added to the reaction mixture in a single portion and stirring was continued for an additional $30 \mathrm{~min}$. Evaporation of the volatiles in vacuo followed by extraction with dichloromethane $(3 \times 50 \mathrm{~mL})$ and filtration through Celite afforded $\mathbf{1 5}$ as a yellow solid in $90 \%$ yield $(0.23 \mathrm{~g}) .{ }^{1} \mathrm{H}$ NMR $\left(200 \mathrm{MHz}, \mathrm{CDCl}_{3}, 25^{\circ} \mathrm{C}\right): \delta=7.54-7.32$ (m, $4 \mathrm{H}, \mathrm{Ar}), 6.50$ (s, $2 \mathrm{H}, \mathrm{Ar}), 4.96$ (s, $\left.2 \mathrm{H}, \mathrm{CH}_{2} \mathrm{O}\right), 3.97$ (s, $4 \mathrm{H}$, $\mathrm{CH}_{2} \mathrm{~N}$ ), 2.92 (s, $12 \mathrm{H}, \mathrm{NMe}_{2}$ ), 0.27 (s, $9 \mathrm{H}, \mathrm{SiMe}_{3}$ ) ppm. ${ }^{13} \mathrm{C} \mathrm{NMR}$ $\left(50 \mathrm{MHz}, \mathrm{CDCl}_{3}, 25{ }^{\circ} \mathrm{C}\right): \delta=156.9,146.5,145.1,140.4,135.8$, 132.6, 132.1, 127.9, 127.8, 127.6, 106.7 (Ar), $74.3\left(\mathrm{CH}_{2} \mathrm{~N}\right), 70.4$ $\left(\mathrm{CH}_{2} \mathrm{O}\right), 52.7\left(\mathrm{NMe}_{2}\right),-1.4\left(\mathrm{SiMe}_{3}\right)$ ppm. $\mathrm{C}_{22} \mathrm{H}_{33} \mathrm{ClN}_{2} \mathrm{OPdSi}$ (511.5): calcd. C 51.66, H 6.50, N 5.48; found C 51.70, H 6.57, N 5.52. ES-MS: calculated for $\mathrm{C}_{22} \mathrm{H}_{33} \mathrm{ClN}_{2} \mathrm{OPdSi}\left[\mathrm{M}^{+}-\mathrm{Cl}\right] 475.1$; found 474.8

(Aqua) \{2,6-Bis[(dimethylamino)methyl]-4-[3-(trimethylsilyl)benzyloxylphenyl palladium(II) Tetrafluoroborate (2): $\mathrm{AgBF}_{4}$ (42 mg, $0.21 \mathrm{mmol})$ was added to a solution of $15(0.10 \mathrm{~g}, 0.20 \mathrm{mmol})$ in wet acetone $(5 \mathrm{~mL})$. A white precipitate formed instantaneously. The reaction mixture was stirred at room temperature for $1 \mathrm{~h}$ and filtered through Celite. Evaporation of the acetone in vacuo afforded $0.12 \mathrm{~g}(>99 \%)$ of pure 2 as a yellow solid. ${ }^{1} \mathrm{H}$ NMR $\left(200 \mathrm{MHz}, \mathrm{CDCl}_{3}, 25^{\circ} \mathrm{C}\right): \delta=7.55-7.36(\mathrm{~m}, 4 \mathrm{H}, \mathrm{Ar}), 6.51(\mathrm{~s}, 2$ $\mathrm{H}, \mathrm{Ar}), 4.96$ (s, $\left.2 \mathrm{H}, \mathrm{CH}_{2} \mathrm{O}\right), 3.98$ (s, $\left.4 \mathrm{H}, \mathrm{CH}_{2} \mathrm{~N}\right), 2.92$ (s, $12 \mathrm{H}$, $\mathrm{NMe}_{2}$ ), 0.27 (s, $9 \mathrm{H}, \mathrm{SiMe}_{3}$ ) ppm. ${ }^{13} \mathrm{C} \mathrm{NMR}\left(50 \mathrm{MHz}, \mathrm{CDCl}_{3}, 25\right.$ $\left.{ }^{\circ} \mathrm{C}\right): \delta=157.9,149.5,145.2,140.9,135.9,133.0,132.4,128.1$, 127.9, 127.8, 107.7 ( $\mathrm{Ar}), 73.7\left(\mathrm{CH}_{2} \mathrm{~N}\right), 70.7\left(\mathrm{CH}_{2} \mathrm{O}\right), 52.7\left(\mathrm{NMe}_{2}\right)$, $-1.1\left(\mathrm{SiMe}_{3}\right)$ ppm. $\mathrm{C}_{22} \mathrm{H}_{35} \mathrm{BF}_{4} \mathrm{~N}_{2} \mathrm{O}_{2} \mathrm{PdSi}$ (580.8): calcd. C 45.49, $\mathrm{H}$ 6.07, N 4.82; found 45.38, H 6.16, N 4.75.

1-(3-Bromobenzyloxy)pyrene (16): $\mathrm{K}_{2} \mathrm{CO}_{3}(3.45 \mathrm{~g}, 25 \mathrm{mmol})$ was added to a stirred solution of 1-pyrenol (6) $(1.09 \mathrm{~g}, 5 \mathrm{mmol}), 3-$ bromobenzyl bromide $(1.22 \mathrm{~g}, 4.9 \mathrm{mmol})$ and 18-crown-6 $(0.13 \mathrm{~g}$, $0.5 \mathrm{mmol})$ in THF $(30 \mathrm{~mL})$, and the mixture was stirred at room temperature for $36 \mathrm{~h}$. The volatiles were evaporated in vacuo and the residue was extracted with dichloromethane $(3 \times 50 \mathrm{~mL})$. The combined dichloromethane extracts were concentrated in vacuo. Purification by flash chromatography (basic $\mathrm{Al}_{2} \mathrm{O}_{3} ; \mathrm{CH}_{2} \mathrm{Cl}_{2}$ ) afforded $1.70 \mathrm{~g}(90 \%)$ of pure $\mathbf{1 6}$ as a yellow oil. ${ }^{1} \mathrm{H}$ NMR $(200 \mathrm{MHz}$, $\left.\mathrm{CDCl}_{3}, 25{ }^{\circ} \mathrm{C}\right): \delta=8.51\left(\mathrm{~d},{ }^{3} J_{\mathrm{H}, \mathrm{H}}=9.2 \mathrm{~Hz}, 1 \mathrm{H}\right.$, pyrenyl), 8.12-7.87 (m, $7 \mathrm{H}$, pyrenyl), 7.77 (s, $1 \mathrm{H}, \mathrm{Ar}), 7.57-7.47$ (m, $3 \mathrm{H}$, pyrenyl), 7.30 (dd, $1 \mathrm{H}, \mathrm{Ar}), 5.40$ (s, $\left.2 \mathrm{H}, \mathrm{CH}_{2} \mathrm{O}\right) \mathrm{ppm} .{ }^{13} \mathrm{C} \mathrm{NMR}$ $\left(50 \mathrm{MHz}, \mathrm{CDCl}_{3}, 25{ }^{\circ} \mathrm{C}\right): \delta=152.0,139.2,131.5,131.4,130.8$, $130.0,129.9,127.2,127.0,126.4,126.0,125.5,125.5,125.1,125.0$, 124.6, 124.2, 124.1, 122.5, 120.9, 120.2, $109.1(\mathrm{Ar}), 69.4\left(\mathrm{CH}_{2} \mathrm{O}\right)$ ppm. $\mathrm{C}_{23} \mathrm{H}_{15} \mathrm{BrO}$ (387.3): calcd. C 71.33, H 3.90; found C 71.39, $\mathrm{H}$ 3.92. ES-MS: calculated for $\mathrm{C}_{23} \mathrm{H}_{15} \mathrm{BrO}\left[\mathrm{M}^{+}\right]$386.0; found 386.6.

1-[3-(Trimethylsilyl)benzyloxylpyrene (3): $t \mathrm{BuLi}$ (1.5 M in pentane, $1.65 \mathrm{~mL}, 2.48 \mathrm{mmol})$ was added dropwise to a precooled $\left(-100{ }^{\circ} \mathrm{C}\right)$ solution of $16(0.48 \mathrm{~g}, 1.24 \mathrm{mmol})$ in THF $(15 \mathrm{~mL})$ and the reaction mixture was stirred for $1 \mathrm{~h}$ at $-100{ }^{\circ} \mathrm{C}$. Trimethylsilyl chloride $(0.30 \mathrm{~mL}, 2.50 \mathrm{mmol})$ was added dropwise to the dark-red solution and the reaction mixture was allowed to warm to room temperature. The volatiles were evaporated in vacuo and the residue was extracted with dichloromethane and filtered through Celite. Evaporation of the dichloromethane in vacuo afforded $0.44 \mathrm{~g}(93 \%)$ of 3 as a yellow oil. ${ }^{1} \mathrm{H}$ NMR $\left(200 \mathrm{MHz}, \mathrm{CDCl}_{3}, 25^{\circ} \mathrm{C}\right): \delta=8.52(\mathrm{~d}$, ${ }^{3} J_{\mathrm{H}, \mathrm{H}}=9.2 \mathrm{~Hz}, 1 \mathrm{H}$, pyrenyl), 8.08-7.80 (m, $7 \mathrm{H}$, pyrenyl, Ar), 7.74 (s, $1 \mathrm{H}$, pyrenyl) $7.58-7.38(\mathrm{~m}, 4 \mathrm{H}, \mathrm{Ar}), 5.33\left(\mathrm{~s}, 2 \mathrm{H}, \mathrm{CH}_{2} \mathrm{O}\right)$, 0.33 (s, $\left.9 \mathrm{H}, \mathrm{SiMe}_{3}\right) \mathrm{ppm} .{ }^{13} \mathrm{C}\left(50 \mathrm{MHz}, \mathrm{CDCl}_{3}, 25^{\circ} \mathrm{C}\right): \delta=152.6$, $140.7,132.9,132.3,131.6,131.5,130.9,128.0,127.9,127.7,127.1$, $126.3,125.9,125.7,125.3,124.9,124.8,124.1,124.0,121.2,120.4$, 109.3 (Ar), $70.9\left(\mathrm{CH}_{2} \mathrm{O}\right)$ ppm. $\mathrm{C}_{26} \mathrm{H}_{24} \mathrm{OSi}$ (380.6): calcd. C 82.06, $\mathrm{H}$ 6.36, Si 7.38; found C 81.89, H 6.38, Si 7.26. ES-MS: calculated for $\mathrm{C}_{26} \mathrm{H}_{24} \mathrm{OSi}\left[\mathrm{M}^{+}\right]$380.2; found 380.7 .

1,3-Bis[(1-pyrenyloxy)methyl]-5-(trimethylsilyl)benzene (4): $t \mathrm{BuLi}$ $(0.41 \mathrm{~mL}, 1.5 \mathrm{M}$ in pentane, $0.62 \mathrm{mmol})$ was added dropwise to a precooled $\left(-100{ }^{\circ} \mathrm{C}\right)$ solution of $8(0.20 \mathrm{~g}, 0.32 \mathrm{mmol})$ in $\mathrm{THF}$ $(5 \mathrm{~mL})$ and the reaction mixture was stirred at $-100{ }^{\circ} \mathrm{C}$ for $30 \mathrm{~min}$. Excess trimethylsilyl chloride $(0.30 \mathrm{~mL}, 2.50 \mathrm{mmol})$ was added dropwise to the dark-red solution and the reaction mixture was allowed to warm to room temperature. The volatiles were evaporated in vacuo and the residue was extracted with dichloromethane and filtered through Celite. Evaporation of the solvent in vacuo afforded $0.18 \mathrm{~g}(92 \%)$ of $\mathbf{4}$ as a yellowish solid. ${ }^{1} \mathrm{H}$ NMR $\left(300 \mathrm{MHz}, \mathrm{CDCl}_{3}, 25^{\circ} \mathrm{C}\right): \delta=8.58\left(\mathrm{~d},{ }^{3} J_{\mathrm{H}, \mathrm{H}}=9.6 \mathrm{~Hz}, 2 \mathrm{H}\right.$, pyrenyl), 8.25-7.91 (m, $14 \mathrm{H}$, pyrenyl), 7.89 (s, $1 \mathrm{H}, \mathrm{Ar}), 7.83$ (s, $2 \mathrm{H}$, $\mathrm{Ar}), 7.59\left(\mathrm{~d},{ }^{3} \mathrm{~J}_{\mathrm{H}, \mathrm{H}}=8.1 \mathrm{~Hz}, 1 \mathrm{H}\right.$, pyrenyl), $5.47\left(\mathrm{~s}, 4 \mathrm{H}, \mathrm{CH}_{2} \mathrm{O}\right)$, 0.48 (s, $\left.9 \mathrm{H}, \mathrm{SiMe}_{3}\right)$ ppm. ${ }^{13} \mathrm{C}\left(75 \mathrm{MHz}, \mathrm{CDCl}_{3}, 25^{\circ} \mathrm{C}\right): \delta=141.8$, $138.0,132.3,132.0,131.9,127.7,127.5,127.4,126.8,126.4,126.1$, 125.8, 125.7, 125.4, 125.2, 124.6, 124.5, 121.6, 121.0, 109.9 (Ar), $71.2\left(\mathrm{CH}_{2} \mathrm{O}\right),-0.7\left(\mathrm{SiMe}_{3}\right)$ ppm. $\mathrm{C}_{436} \mathrm{H}_{34} \mathrm{O}_{2} \mathrm{Si}$ (5331.1): calcd. C 84.55, H 5.61; found 84.67, H 5.70. ES-MS: calculated for $\mathrm{C}_{43} \mathrm{H}_{34} \mathrm{O}_{2} \mathrm{Si}\left[\mathrm{M}^{+}+\mathrm{H}\right]$ 611.2; found 611.1.

Catalyst Screening: The (substituted) benzaldehyde or cinnamaldehyde $(0.8 \mathrm{mmol})$, (diisopropyl)ethylamine $(10 \mathrm{~mol} \%, 80 \mu \mathrm{mol})$ and methyl isocyanoacetate $(0.8 \mathrm{mmol})$ were added to a solution of the catalyst ( $1 \mathrm{~mol} \%, 8 \mu \mathrm{mol}$ ) in $2.5 \mathrm{~mL}$ of $\mathrm{CH}_{2} \mathrm{Cl}_{2}$. The mixture was stirred in a closed reaction vessel under ambient conditions. Samples $(100 \mu \mathrm{l})$ for ${ }^{1} \mathrm{H} \mathrm{NMR}\left(200 \mathrm{MHz}, \mathrm{CDCl}_{3}, 25^{\circ} \mathrm{C}\right)$ analysis concentrated in a stream of nitrogen gas, and redissolved in $\mathrm{CDCl}_{3}$ $(0.5 \mathrm{~mL})$. Conversions (methyl isocyanoacetate consumptions) were calculated from the intensity of the $\mathrm{CNCH}_{2} \mathrm{COOMe}$ protons versus the combined methyl ester signals.

Fluorescence Spectroscopy: Steady-state fluorescence measurements were carried out with a SPEX Fluorolog 3-22 using a 450-W Xe excitation source and a Peltier-cooled R636-10 photomultiplier by Hamamatsu, operating in photon-counting mode. For time-resolved emission measurements we used a Chromex IS250 spectrograph coupled to a Hamamatsu streak camera (C5680-21 with M5677 Low-Speed Single-Sweep Unit and C4742-95 CCD camera). For excitation an LTB MSG400 nitrogen laser $(337 \mathrm{~nm}$, 
$\mathrm{fwhm} \approx 0.6 \mathrm{~ns}$ ) was used. Lifetimes were determined from monoexponential (Figure 3) or biexponential (Figure 4) fits to the decay curves in the time domain beyond the laser pulse.

Computational Details: Results were obtained utilizing the multiple conformer search as implemented in the SPARTAN 5.1.1 (UNIX) package, with a MMFF94 mechanics force field. ${ }^{[16]}$ The input data used in the conformer searches of both $\mathbf{1}$ and $\mathbf{1 1}$ were imported into the program by using the builder routine in the molecular modeling package followed by a geometry optimization with the MMFF94 mechanics force field. The square-planar geometry of the palladium complexes, known from single-crystal X-ray structures and DFT calculations, is well reproduced by the mechanics force field. Special treatment of the palladium atom in the calculations was therefore omitted. Conformer searches were performed using Monte Carlo and systematic stepwise rotation around the six bonds connecting the NCN ligand and the pyrenoxy unit to the linker, both leading to similar results.

X-ray Crystallographic Study: Crystal data and data collection for 10. Empirical formula $\mathrm{C}_{39} \mathrm{H}_{43} \mathrm{BrN}_{2} \mathrm{O}_{2} \mathrm{Si} \cdot \mathrm{CH}_{2} \mathrm{Cl}_{2}, M_{\mathrm{r}}=764.68$, triclinic, space group $P \overline{1}$ (no. 2), $a=9.9388(2), b=13.2651(3), c=$ $14.7898 \AA, \alpha=84.512(1)^{\circ}, \beta=80.614(1)^{\circ} \gamma=74.891(1)^{\circ}, V=$ $1854.38(7) \AA^{3}, F(000)=796, Z=2, \rho_{\text {calcd. }}=1.370 \mathrm{Mg} / \mathrm{m}^{3}, \mu($ Mo$\left.K_{\alpha}\right)=1.322 \mathrm{~mm}^{-1}, 2 \theta_{\max }=55.0^{\circ} .19551$ reflections measured, 8432 independent, $R_{\text {int }}=0.0349$. Refinement converged at a $w R_{2}$ value of 0.1054 ( $S=1.023), R=0.0408$ [for 7064 reflections with $\left.F_{\mathrm{o}}>4 \sigma\left(F_{\mathrm{o}}\right)\right]$. Maximum residual electron density $0.44 \mathrm{e} / \AA^{3}$. A paleyellow plate crystal $(0.36 \times 0.21 \times 0.09 \mathrm{~mm})$ was mounted under a nitrogen stream $(150 \mathrm{~K})$ on a Nonius Kappa CCD area detector diffractometer with a graphite monochromator $(\lambda=0.71073 \AA$ ), and a rotating anode source. Lorentz, polarization, and absorption corrections (the latter using multiple measured equivalent reflections) were applied (PLATON/MULABS ${ }^{[17 a]}$ ). The structure was solved with the DIRDIF97 ${ }^{[17 \mathrm{c}]}$ program and refined with SHELXL-97 ${ }^{[17 b]}$ using full-matrix least squares on $F^{2}$. All non-hydrogen atoms were refined with anisotropic displacement parameters, hydrogen atoms were located at calculated positions and refined riding on their carrier atoms. The dichloromethane molecule is equally disordered across two positions. CCDC-165285 contains the supplementary crystallographic data for this paper. These data can be obtained free of charge at www.ccdc.cam.ac.uk/conts/ retrieving.html [or from the Cambridge Crystallographic Data Centre, 12 Union Road, Cambridge CB2 1EZ, UK; Fax: (internat.) + 44-1223/336-033; E-mail: deposit@ccdc.cam.ac.uk].

\section{Acknowledgments}

The authors wish to thank Mr. C. Versluis from the Analytical Chemical Department (Utrecht University) for measuring the FAB- and ES-MS spectra. This work was supported by the Council for Chemical Sciences of The Netherlands' Organisation for Scientific Research (CW/NWO), the Dutch Technology Foundation (STW), and the Netherlands Research School Combination Catalysis (NRSC-C).

[1] For overviews on NCN-pincer chemistry see: [1a] M. Albrecht, G. van Koten, Angew. Chem. Int. Ed. 2001, 40, 3750-3781. [1b] P. Steenwinkel, R. A. Gossage, G. van Koten, Chem. Eur. J. 1998, 4, 759-763. ${ }^{[1 \mathrm{c}]}$ R. A. Gossage, L. A. van de Kuil, G. van Koten, Acc. Chem. Res. 1998, 31, 423-431. ${ }^{[1 \mathrm{~d}]}$ M. H. P.
Rietveld, D. M. Grove, G. van Koten, New J. Chem. 1997, 21, 751. ${ }^{[1 \mathrm{e}]}$ G. van Koten, Pure Appl. Chem. 1989, 61, 1681.

${ }^{[2]}[2 \mathrm{a}]$ G. Rodríguez, M. Albrecht, J. Schoenmaker, A. Ford, M. Lutz, A. L. Spek, G. van Koten, J. Am. Chem. Soc. 2002, 124, 5127-5138. ${ }^{[2 b]}$ M. Q. Slagt, R. J. M. Klein Gebbink, M. Lutz, A. L. Spek, G. van Koten, J. Chem. Soc., Dalton Trans. 2002, 252591-252592.

[3] For overviews on catalytically active metallodendritic complexes, see: ${ }^{[3 a]}$ R. Heerbeek, P. C. J. Kamer, P. W. N. M. van Leeuwen, J. N. H. Reek, Chem. Rev. 2002, 102, 3717-3756. [3b] R. Kreiter, A. W. Kleij, R. J. M. Klein Gebbink, G. van Koten, Top. Curr. Chem. 2001, 217, 163-199. ${ }^{[3 \mathrm{c}]}$ G. E. Oosterom, J. H. N. Reek, P. C. J. Kamer, P. W. N. M. van Leeuwen, Angew. Chem. Int. Ed. 2001, 40, 1828-1849. ${ }^{[3 \mathrm{~d}]}$ D. Astruc, F. Chardac, Chem. Rev. 2001, 101, 2991-2023.

[4] G. Rodríguez, M. Lutz, A. L. Spek, G. van Koten, Chem. Eur. J. 2002, 8, 45-57.

[5] [5a] H. P. Dijkstra, G. P. M. van Klink, G. van Koten, Acc. Chem. Res. 2002, 35, 798-810. ${ }^{[5 b]}$ A. W. Kleij, R. A. Gossage, J. T. B. H. Jastrzebski, J. Boersma, G. van Koten, Angew. Chem. 2000, 39, 176-178. ${ }^{[5 c]}$ P. Wijkens, J. T. B. H. Jastrzebski, P. A. van der Schaaf, R. Kolly, A. Hafner, G. van Koten, Org. Lett. 2000, 11, 1621-1624. [5d] U. Kragl, C. Dreisbach, Angew. Chem. Int. Ed. Engl. 1996, 35, 342. ${ }^{[5]}$ U. Kragl, C. Dreisbach, C. Wandrey, "Applied Homogeneous Catalysis with Organometallic Compounds" in Membrane Reactors in Homogeneous Catalysis (Eds.: B. Cornils, W. A. Herrmann), WileyVCH, Weinheim, 1996, p. 833-843.

[6] [6a] J.-M. Valk, R. van Belzen, J. Boersma, A. L. Spek, G. van Koten, J. Chem. Soc., Dalton Trans. 1994, 2293. [6b] J.-M. Valk, J. Boersma, G. van Koten, J. Orgmet. Chem. 1994, 483, 213.

[7] [7a] P. Steenwinkel, R. A. Gossage, G. van Koten, Chem. Eur. J. 1998, 4, 759-762. ${ }^{[7 b]}$ P. Steenwinkel, J. T. B. H. Jastrzebski, B.-J. Deelman, D. M. Grove, H. Kooijman, N. Veldman, W. J. J. Smeets, A. L. Spek, G. van Koten, Organometallics 1997, $16,5486-5498$.

${ }^{[8]}$ Overviews and studies involving hypervalent/pentacoordinate silicon atoms: ${ }^{[8 a]}$ J. M. Anglada, C. Bo, J. M. Bofill, R. Crehuet, J. M. Poblet, Organometallics 1999, 18, 5584-5593. [8b] M. Weinmann, A. Gehring, B. Schiemenz, G. Huttner, B. Nuber, G. Rheinwald, H. Lang, J. Orgmet. Chem. 1998, 563, $61-72 .{ }^{[8 c]}$ W. Ziche, B. Ziemer, P. John, J. Weis, N. Auner, J. Orgmet. Chem. 1997, 531, 245. ${ }^{[8 \mathrm{~d}]}$ R. R. Holmz, Chem. Rev. 1996, 96, 927-950. ${ }^{[8 \mathrm{e}]}$ C. Chuit, R. J. P. Corriu, C. Reye, J. C. Young, Chem. Rev. 1993, 93, 1371-1448. ${ }^{[8 f]}$ H. Handwerker, C. Leis, R. Probst, P. Bissenger, A. Grohmann, P. Kiprof, E. Herdtureck, J. Blümel, N. Auner, C. Zybill, Organometallics 1993, 12, 2162.

[9] Good FFCE (face-to-face, center-to-edge) stacking is present in cases where the stacking parameters fulfil the following requirements: $\alpha<45^{\circ}, 1.4 \AA<x<2.7 \AA$ and $3.3 \AA<z<4.0$ A $(\alpha=$ angle between planes, $x=$ horizontal displacement, $z=$ vertical displacement). See also: C. B. Martin, H. R. Mulla, P. G. Willis, A. Cammers-Goodwin, J. Org. Chem. 1999, 64, $7802-7806$

${ }^{[10]}$ For fluorescence and adsorption spectra of 1a and 11a, see Supporting Information (see also the footnote on the first page of this article).

[11] J. Granot, J. Magn. Res. 1983, 55, 216.

${ }^{[12]}$ K. A. Connors, Binding Constants, The Measurement of Molecular Complex Stability, Wiley-Interscience, New York, 1987, p. 24-28.

${ }^{[13]}$ Examples of $\mathrm{Pd}^{\mathrm{II}}$ - and $\mathrm{Pt}^{\mathrm{II}}$-catalyzed aldol condensations: ${ }^{[13 a]}$ H. P. Dijkstra, M. D. Meijer, J. Patel, R. Kreiter, G. P. M. van Klink, M. Lutz, A. L. Spek, A. J. Canty, G. van Koten, Organometallics 2001, 20, 3159-3168. ${ }^{[13 \mathrm{~b}]}$ M. A. Stark, C. J. Richards, Tetrahedron Lett. 1997, 38, 5881-5884. [13c] J. M. Longmire, X. Zhang, Organometallics 1998, 17, 4374-4379. ${ }^{[13 d]}$ O. Fujimura, J. Am. Chem. Soc. 1998, 120, 10032-10039. 
${ }^{[13 e]}$ F. Gorla, A. Togni, L. M. Venanzi, A. Albinati, F. Lianza, Organometallics 1994, 13, 1607-1616. ${ }^{[13 f]} \mathrm{R}$. Nesper, P. S. Pregosin, K. Püntener, M. Wörle, Helv. Chim. Acta 1993, 76, 2239; see also ref. ${ }^{[4]}$

[14] [14a] T. Hayashi, M. Sawamura, Y. Ito, Tetrahedron 1992, 48, 1999-2012. [14b] V. A. Soloshonok, T. Hayashi, Tetrahedron Lett. 1994, 35, 2713-2716. ${ }^{[14 c]}$ A. Togni, S. D. Pastor, J. Org. Chem. 1990, 55, 1649.

[15] [15a] P. J. Davies, D. M. Grove, G. van Koten, Organometallics 1997, 16, 800-802. ${ }^{[15 b]}$ W. T. S. Huck, F. C. J. M. van Veggel, B. L. Kropman, D. H. A. Blank, E. G. Keim, M. M. A. Smithers, D. N. Reinhoudt, J. Am. Chem. Soc. 1995, 117, 8293.
[16] SPARTAN SGI, version 5.1.1, Wavefunction, Inc., 18401 Von Karman Ave., Ste. 370, Irvine, CA 92612, USA.

[17] [17a] A. L. Spek, PLATON, A multipurpose crystallographic tool, Utrecht University, The Netherlands, 2000. ${ }^{[17 b]}$ G. M. Sheldrick, SHELXL-97, Program for crystal structure refinement, University of Göttingen, Germany, 1997. ${ }^{[17 \mathrm{c}]} \mathrm{P}$. T. Beurskens, G. Admiraal, G. Beurskens, W. P. Bosman, S. Garcia-Granda, R. O. Gould, J. M. M. Smits, C. Smykalla, DIRDIF97 Program System, Technical Report. Crystallography Laboratory, University of Nijmegen, The Netherlands, 1997.

Received October 30, 2002 